кuLTura- мeDia- теоLogia

ISSN 2081-8971

$2017 \mathrm{nr} 29$, s. 172-203.

\title{
Treść tematów okładkowych w magazynach a reakcje polskich odbiorców
}

\author{
Magazines covers' topics content and reactions of Polish audiences.
}

\section{STRESZCZENIE:}

NINIEJSZY ARTYKU€ JEST KONTYNUACJĄ BADAŃ NAD

TEMATAMI OKŁADKOWYMI, EKSPONOWANYMI NA FRONTOWYCH OKŁADKACH MAGAZYNÓW. PRZEDMIOTEM BADAŃ JEST TREŚĆ TYCH TEMATÓW. CEL GŁÓWNY ANALIZY TO ZBADANIE REAKCJI POLSKICH ODBIORCÓW NA TREŚĆ TEMATÓW OKŁADKOWYCH. POZOSTAŁE CELE SFORMUŁOWANO JAKO ZAMIAR PRZEDSTAWIENIA: 1) WPŁYWU KATEGORII DEMOGRAFICZNYCH (PŁCI, WIEKU, WYKSZTAECENIA I MIEJSCA ZAMIESZKANIA) RESPONDENTÓW NA ODBIÓR TREŚCI TEMATÓW OKŁADKOWYCH; 2) NAJPOPULARNIEJSZYCH I NAJMNIEJ POPULARNYCH TREŚCI TEMATÓW OKŁADKOWYCH DLA PRZEDSTAWICIELI KAŻDEJ WSPOMNIANEJ KATEGORII DEMOGRAFICZNEJ. AUTORKA WERYFIKUJE HIPOTEZE: DOBÓR TREŚCI TEMATÓW OKŁADKOWYCH WIĄŻE SIĘ Z REAKCJAMI POLSKICH ODBIORCÓW, ZACHĘCAJĄC LUB ZNIECHĘCAJĄC DO KONTAKTU Z WYDANIEM MAGAZYNU, PRZY CZYM DECYZJE ODBIORCÓW UWARUNKOWANE SĄ ICH

PRZYNALEŻNOŚCIĄ DO WZMIANKOWANYCH KATEGORII DEMOGRAFICZNYCH. FUNDAMENTEM PRZEDSTAWIANEGO TEKSTU SĄ WŁASNE BADANIA ILOŚCIOWE,

PRZEPROWADZONE METODĄ ANKIETOWĄ ZA POMOCĄ TECHNIKI CAWI. ZREALIZOWANO JE W DNIACH 2-6 WRZEŚNIA 2016 R. NA OGÓLNOPOLSKIEJ PRÓBIE POLAKÓW ( $\mathrm{N}=1094)$, DOBRANEJ Z PANELU ARIADNA.

\section{SŁOWA KLUCZOWE:}

TEMATY OKŁADKOWE, TREŚĆ TEMATÓW OKŁADKOWYCH, OKŁADKI, MAGAZYNY, PRASA

\begin{abstract}
:
THIS ARTICLE IS A CONTINUATION OF RESEARCH ON COVER TOPICS, DISPLAYED ON THE FRONT COVER OF MAGAZINES. THE SUBJECT OF RESEARCH IS THE CONTENT OF THESE TOPICS. THE MAIN PURPOSE OF THE ANALYSIS IS TO INVESTIGATE THE REACTION OF POLISH AUDIENCES TO THE CONTENT OF THE COVERS. OTHER GOALS ARE TO PRESENT: 1) THE IMPACT OF DEMOGRAPHIC CATEGORIES (GENDER, AGE, EDUCATION AND PLACE OF RESIDENCE) ON THE RECEPTION OF COVER' TOPICS CONTENT; 2) THE MOST POPULAR AND LEAST POPULAR COVER TOPICS FOR THE REPRESENTATIVES OF EACH OF THESE DEMOGRAPHIC CATEGORIES. THE AUTHOR VERIFIES THE FOLLOWING HYPOTHESIS: THE SELECTION OF COVER' TOPICS CONTENT AFFECTS THE REACTIONS OF POLISH AUDIENCE, ENCOURAGING OR DISCOURAGING THEM TO CHOOSING A GIVEN MAGAZINE. HOWEVER, THE DECISIONS OF THE CUSTOMERS ARE CONNECTED WITH ABOVE MENTIONED DEMOGRAPHIC CATEGORIES. THE FOUNDATIONS OF THE PRESENTED TEXT IS QUANTITATIVE SURVEY, CONDUCTED BY CAWI (COMPUter Assisted Web INTERVIEWS). IT WAS CONDUCTED ON SEPTEMBER 2-6TH 2016 ON A NATIONWIDE SAMPLE OF POLES COUNTING N $=1094$ PEOPLE, SELECTED FROM ARIADNA PANEL.
\end{abstract}

\section{KEYWORDS:}

COVER TOPICS, THE CONTENT OF COVER TOPICS, COVERS, MAGAZINES, PRESS 
$\mathrm{N}$ iniejszy artykuł jest kontynuacją badań nad tematami okładkowymi, eksponowanymi na frontowych okładkach magazynów. O ile w tekście pt. „Tematy okładkowe polskich magazynów - elementy składowe i preferencje odbiorców" określono rolę i formę tematów okładkowych, o tyle tutaj za przedmiot badań przyjęto treść tychże tematów (wyrażaną zarówno w postaci tekstowej, jak i ilustracyjnej).

\section{Założenia metodologiczne}

$\mathrm{Z}$ racji skromnej liczby polskich opracowań naukowych, poświęconych zagadnieniu okładek w kontekście marketingu medialnego (a tym bardziej tematów okładkowych lub ich treści), autorka skupiła się na analizie wyników własnych badań ilościowych, przeprowadzonych metodą ankietową za pomocą techniki CAWI (tzw. Computer Assisted Web Interviews). Zrealizowano je w dniach 2-6 września 2016 roku na ogólnopolskiej próbie Polaków liczącej N=1094 osób, dobranej z panelu Ariadna ${ }^{1}$. Na potrzeby tego tekstu autorka wybrała fragmenty badań związane z jego tytułem, koncentrując się na - co jest głównym celem tej analizy - zbadaniu reakcji polskich odbiorców na treść tematów okładkowych. Pozostałe cele sformułowano jako zamiar przedstawienia:

- wpływu kategorii demograficznych (płci, wieku, wykształcenia i miejsca zamieszkania) na odbiór treści tematów okładkowych;

- najpopularniejszych i najmniej popularnych treści tematów okładkowych dla przedstawicieli każdej wspomnianej kategorii demograficznej.

Autorka dąży do weryfikacji następującej hipotezy: dobór treści tematów okładkowych wiąże się z reakcjami polskich odbiorców, zachęcając lub zniechęcając ich do kontaktu z danym wydaniem magazynu, przy czym decyzje odbiorców uwarunkowane są ich przynależnością do wzmiankowanych kategorii demograficznych (co w sposób bezpośredni wiąże się z prowadzeniem działalności wydawniczej).

Aby dokładnie przeprowadzić badania stosunku Polaków do omawianego zagadnienia, w ankiecie wskazano 24 motywy $^{2}$, które przenalizowano w kontekście szczegółowych reakcji (od zwracania uwagi do zniechęcania do zakupu) demograficznie zróżnicowanych odbiorców. Z racji ilości danych, autorka zdecydowała się na tabelaryczne ujęcie wyników. Podjęła także próbę określenia, które tematy są przez odbiorców odbierane pozytywnie (czyli w jakim stopniu zwracają uwagę, zachęcają do przeglądania i kupowania), a które negatywnie (jak zniechęcają do przeglądania i kupowania). W tym celu:

- uporządkowała kolejność motywów według liczby wskazań, które zaznaczali respondenci (od wyniku najgorszego do najlepszego);

\footnotetext{
Dokładny opis badań przedstawiono w artykule autorki pt. „Tematy okładkowe polskich magazynów elementy składowe i preferencje odbiorców” publikowanym w numerze 28 kwartalnika „Kultura-Media-Teologia”. Więcej o panelu: https://panelariadna.pl/userpanel.php (dostęp 15.05.2017 r.).

2 Były to: wulgarność, politycy i polityka, religia, przemoc, sport, publicystyka, nauka, gwiazdy popkultury, erotyka, motoryzacja, biznes i ekonomia, poradnictwo, historie z życia wzięte, gry komputerowe, historia, moda, technologia, informacja, rodzicielstwo/dzieci, uroda, kulinaria, kultura, hobby, inne.
} 


\section{OBLICZA MEDIÓW I KOMUNIKACJI}

- w każdej kolumnie wszystkich tabel wybrała po pięć najgorzej i najlepiej odbieranych motywów, przyporządkowując je jednocześnie do działań pozytywnych i negatywnych.

Należy zaznaczyć, że pełną tabelę przedstawiono tylko raz - dla wyników uśrednionych - zaś w dalszej części artykułu zaprezentowano dane pokazujące wyimek z badań, czyli po pięć najlepszych i najgorszych rezultatów każdego oddziaływania pozytywnego i negatywnego.

\section{Treść tematów okładkowych a reakcje odbiorców - dane uśrednione}

Wyniki uśrednione dla wszystkich badanych przedstawia tabela 1. Zgodnie z przyjętymi założeniami, biorąc pod uwagę pozytywne oddziaływanie tematów okładkowych, można zauważyć, że:

- uwagę w najmniejszym stopniu zwracają wulgarność, politycy i polityka, religia, przemoc i sport; zaś w największym - uroda, kulinaria, kultura, hobby i tzw. inne;

- do przejrzenia pisma najmniej zachęcają wulgarność, erotyka, gry komputerowe, politycy i polityka oraz przemoc; zaś najbardziej - poradnictwo, technologia, kultura, historia i nauka;

- tematy okładkowe, które wpływają na zakup magazynów, to w najmniejszych stopniu wulgarność, przemoc, politycy i polityka, erotyka i religia; zaś w największym: historie z życia wzięte, kulinaria, nauka, poradnictwo i informacja;

Z kolei, biorąc pod uwagę negatywne oddziaływanie tematów okładkowych, można zauważyć, że:

- najrzadziej zniechęcają: informacja, hobby, poradnictwo, nauka i technologia; najczęściej - gry komputerowe, erotyka, przemoc, politycy i polityka oraz wulgarność;

- do kupna magazynu demotywują najmniej technologia, kulinaria, nauka, poradnictwo i inne; za to najbardziej - przemoc, politycy i polityka, religia, erotyka i wulgarność.

Patrząc na uśrednione wyniki badań widać wyraźnie, że istnieje pewna grupa tematów, które powtarzają się przynajmniej raz w poszczególnych odpowiedziach. Wydaje się, że to na nich powinni skupiać się wydawcy, albo po nie sięgając, albo się ich wystrzegając. W pozytywnym oddziaływaniu najlepiej wypadają informacja, kulinaria i nauka, zaś w negatywnym - erotyka, przemoc, polityka i wulgarność. Odpowiedzi dokumentujące zniechęcenie są tu bardzo jednoznaczne - warto podkreślić, że dla aż 40,1\% respondentów polityka na okładce to motyw zniechęcający do przeglądania pisma. Co ciekawe, polityka, wulgarność i przemoc znalazły się także na najgorszych miejscach zestawień wskazujących pozytywne oddziaływanie tematów okładkowych - udowadnia to wyjątkową niechęć Polaków do tych motywów i ich negatywny wpływ na kupno czy choćby przejrzenie pisma. 
A. Jupowicz-Ginalska, Treść tematów okładkowych w magazynach...

\begin{tabular}{|c|c|c|c|c|c|c|c|c|c|}
\hline & $\begin{array}{c}\text { Zwracają moją } \\
\text { uwagę }\end{array}$ & & $\begin{array}{l}\text { Zachęcają mnie do } \\
\text { przejrzenia pisma }\end{array}$ & & \begin{tabular}{|l|} 
Zachẹcają mnie \\
do kupna pisma
\end{tabular} & & \begin{tabular}{|c} 
Zniechęcają mnie \\
do przejrzenia \\
pisma
\end{tabular} & & \begin{tabular}{|c|} 
Zniechęcają \\
mnie do kupna \\
pisma
\end{tabular} \\
\hline Wulgarność & $9,4 \%$ & Wulgarność & $5,8 \%$ & Wulgarność & $8,4 \%$ & Informacja & $7,9 \%$ & Technologia & $7,7 \%$ \\
\hline Politycy i polityka & $13,9 \%$ & Erotyka & $10,2 \%$ & Przemoc & $10,9 \%$ & Hobby & $9,4 \%$ & Kulinaria & $8,0 \%$ \\
\hline Religia & $18,2 \%$ & \begin{tabular}{|l|} 
Gry \\
komputerowe
\end{tabular} & $10,9 \%$ & \begin{tabular}{|l}
$\begin{array}{l}\text { Politycy i } \\
\text { polityka }\end{array}$ \\
\end{tabular} & $12,0 \%$ & Poradnictwo & $10,9 \%$ & Nauka & $8,2 \%$ \\
\hline Przemoc & $18,2 \%$ & \begin{tabular}{|l}
$\begin{array}{l}\text { Politycy i } \\
\text { polityka }\end{array}$ \\
\end{tabular} & $12,6 \%$ & Erotyka & $14,5 \%$ & Nauka & $12,0 \%$ & Poradnictwo & $8,6 \%$ \\
\hline Sport & $18,6 \%$ & Przemoc & $12,7 \%$ & Religia & $15,1 \%$ & Technologia & $13,4 \%$ & Inne & $8,7 \%$ \\
\hline Publicystyka & $19,5 \%$ & Religia & $16,3 \%$ & \begin{tabular}{|l}
$\begin{array}{l}\text { Biznes i } \\
\text { ekonomia }\end{array}$ \\
\end{tabular} & $15,8 \%$ & $\begin{array}{l}\begin{array}{l}\text { Historie z życia } \\
\text { wzięte }\end{array} \\
\end{array}$ & $13,5 \%$ & Hobby & $8,7 \%$ \\
\hline Nauka & $19,6 \%$ & Motoryzacja & $17,9 \%$ & \begin{tabular}{|l|}
$\begin{array}{l}\text { Gry } \\
\text { komputerowe }\end{array}$ \\
\end{tabular} & $16,0 \%$ & Inne & $14,3 \%$ & Informacja & $8,8 \%$ \\
\hline Gwiazdy popkultury & $19,8 \%$ & Inne & $19,0 \%$ & \begin{tabular}{|l} 
Gwiazdy \\
popkultury
\end{tabular} & $16,7 \%$ & Kultura & $14,3 \%$ & Kultura & $9,3 \%$ \\
\hline Erotyka & $20,3 \%$ & Sport & $19,1 \%$ & Historia & $18,7 \%$ & Kulinaria & $15,1 \%$ & \begin{tabular}{|l}
$\begin{array}{l}\text { Rodzicielstwo / } \\
\text { dzieci }\end{array}$ \\
\end{tabular} & $9,7 \%$ \\
\hline Motoryzacja & $21,0 \%$ & \begin{tabular}{|l|} 
Gwiazdy \\
popkultury
\end{tabular} & $19,5 \%$ & Sport & $20,3 \%$ & $\begin{array}{l}\text { Rodzicielstwo / } \\
\text { dzieci }\end{array}$ & $16,6 \%$ & Historia & $11,2 \%$ \\
\hline Bizmes i ekonomia & $21,7 \%$ & Uroda & $19,8 \%$ & Kultura & $20,6 \%$ & Historia & $17,0 \%$ & Moda & $13,2 \%$ \\
\hline Poradnictwo & $22,6 \%$ & Moda & $21,4 \%$ & Motoryzacja & $21,6 \%$ & Publicystyka & $18,0 \%$ & Uroda & $13,3 \%$ \\
\hline Historie z życia wzięte & $22,8 \%$ & $\begin{array}{l}\text { Historie z życia } \\
\text { wzięte }\end{array}$ & $22,2 \%$ & $\begin{array}{l}\text { Rodzicielstwo / } \\
\text { dzieci }\end{array}$ & $22,1 \%$ & Uroda & $18,1 \%$ & Publicystyka & $13,3 \%$ \\
\hline Gry komputerowe & $23,2 \%$ & Kulinaria & $24,0 \%$ & Moda & $22,2 \%$ & Moda & $20,0 \%$ & \begin{tabular}{|l}
$\begin{array}{l}\text { Historie z życia } \\
\text { wzięte }\end{array}$ \\
\end{tabular} & $14,6 \%$ \\
\hline Historia & $23,2 \%$ & $\begin{array}{l}\text { Rodzicielstwo / } \\
\text { dzieci }\end{array}$ & $26,5 \%$ & Publicystyka & $22,6 \%$ & $\begin{array}{l}\text { Biznes i } \\
\text { ekonomia }\end{array}$ & $20,1 \%$ & $\begin{array}{l}\text { Biznes i } \\
\text { ekonomia }\end{array}$ & $15,1 \%$ \\
\hline Moda & $23,3 \%$ & Publicystyka & $26,6 \%$ & Uroda & $23,6 \%$ & Sport & $21,8 \%$ & \begin{tabular}{|l} 
Gwiazdy \\
popkultury
\end{tabular} & $16,8 \%$ \\
\hline Technologia & $23,4 \%$ & Hobby & $26,6 \%$ & Inne & $24,8 \%$ & Motoryzacja & $22,2 \%$ & Motoryzacja & $17,3 \%$ \\
\hline Informacja & $24,8 \%$ & \begin{tabular}{|l|}
$\begin{array}{l}\text { Biznes i } \\
\text { ekonomia }\end{array}$ \\
\end{tabular} & $27,3 \%$ & Hobby & $26,4 \%$ & \begin{tabular}{|l|}
$\begin{array}{l}\text { Gwiazdy } \\
\text { popkultury }\end{array}$ \\
\end{tabular} & $27,2 \%$ & \begin{tabular}{|l|} 
Gry \\
komputerowe
\end{tabular} & $18,9 \%$ \\
\hline \begin{tabular}{|l|} 
Rodzicielstwo / dzieci \\
\end{tabular} & $25,2 \%$ & Informacja & $28,0 \%$ & Technologia & $26,8 \%$ & Religia & $27,4 \%$ & Sport & $20,2 \%$ \\
\hline Uroda & $25,3 \%$ & Poradnictwo & $28,7 \%$ & $\begin{array}{l}\text { Historie z życia } \\
\text { wzięte }\end{array}$ & $26,9 \%$ & \begin{tabular}{|l|} 
Gry \\
komputerowe
\end{tabular} & $31,1 \%$ & Przemoc & $21,1 \%$ \\
\hline Kulinaria & $25,9 \%$ & Technologia & $28,8 \%$ & Kulinaria & $27,0 \%$ & Erotyka & $32,0 \%$ & \begin{tabular}{|l}
$\begin{array}{l}\text { Politycy i } \\
\text { polityka }\end{array}$ \\
\end{tabular} & $21,5 \%$ \\
\hline Kultura & $26,6 \%$ & Kultura & $29,2 \%$ & Nauka & $28,6 \%$ & Przemoc & $37,1 \%$ & Religia & $23,0 \%$ \\
\hline Hobby & $28,8 \%$ & Historia & $29,8 \%$ & Poradnictwo & $29,2 \%$ & \begin{tabular}{|l}
$\begin{array}{l}\text { Politycy i } \\
\text { polityka }\end{array}$ \\
\end{tabular} & $40,1 \%$ & Erotyka & $23,0 \%$ \\
\hline Inne & $33,2 \%$ & Nauka & $31,6 \%$ & Informacja & $30,5 \%$ & Wulgarność & $41,3 \%$ & Wulgarność & $35,2 \%$ \\
\hline
\end{tabular}

Tabela 1. Treść tematów okładkowych a reakcje odbiorców (dane uśrednione). Źródło: opracowanie własne na podstawie badań przeprowadzonych na ogólnopolskiej próbie liczącej N=1094 osób, dobranej z panelu Ariadna metodą CAWI. Odpowiadający: wszyscy badani.

\section{Treść tematów okładkowych a reakcje odbiorców - dane w kontekście kategorii demograficznych 3.1. Płeć}

Kolejne dwie tabele - numery 2 (dla kobiet) i 3 (dla mężczyzn) - przedstawiają wyniki badań ze względu na płeć badanych. W przypadku kobiet (mowa o pozytywnym działaniu):

- uwagę w najmniejszym stopniu zwracają wulgarność, erotyka, politycy i polityka, gwiazdy popkultury i nauka; zaś w największym - kulinaria, historie z życia wzięte, hobby, uroda i tzw. inne;

- do przejrzenia pisma najmniej zachęcają erotyka, wulgarność, gry komputerowe, motoryzacja i przemoc; zaś najbardziej - historia, technologia, informacja, kultura i nauka;

- tematy okładkowe, które wpływają na zakup magazynów, to w najmniejszym stopniu wulgarność, przemoc, politycy i polityka, biznes, ekonomia, erotyka; zaś w największym: historie z życia wzięte, hobby, informacja, kulinaria i poradnictwo.

Z kolei, biorąc pod uwagę negatywne oddziaływanie tematów okładkowych, zauważono, że: 
- najrzadziej do przejrzenia zniechęcają informacja, uroda, poradnictwo, kultura i hobby; najczęściej - przemoc, gry komputerowe, politycy i polityka, erotyka i wulgarność;

- do kupna magazynu demotywują najmniej kulinaria, tzw. inne, moda, rodzicielstwo i uroda; za to najbardziej - gry komputerowe, politycy i polityka, przemoc, erotyka i wulgarność.

Panie dokładnie wiedzą, jakie tematy okładek im się nie podobają, udzielając podobnych odpowiedzi na pytania o zniechęcenie do przeglądania i kupowania magazynu. Wśród powtarzających się motywów w zakresie pozytywnego oddziaływania tematów okładkowych najsłabiej wypadły wulgarność, erotyka, politycy i polityka i przemoc. Najwięcej najlepszych odpowiedzi zyskały kulinaria, historie z życia wzięte, hobby i informacja. W negatywnym oddziaływaniu respondentki jako najmniej zniechęcające uznały urodę, zaś najbardziej - przemoc, gry komputerowe, polityków i politykę, erotykę i wulgarność. Warto też zaznaczyć, że te odpowiedzi wpisują się nieco, niestety, w stereotypowe określenie gustów kobiecych, co potwierdzają dobre pozycje kulinariów, poradnictwa, historii z życia wziętych czy urody.

\begin{tabular}{|c|c|c|c|c|c|c|c|c|c|}
\hline \multicolumn{10}{|c|}{ Pięć najmniej licznych wskazań na poszczególne motywy - kobiety } \\
\hline & $\begin{array}{c}\text { Zwracają moją } \\
\text { uwagę }\end{array}$ & & $\begin{array}{l}\text { Zachęcają mnie do } \\
\text { przejrzenia pisma }\end{array}$ & & $\begin{array}{l}\text { Zachęcają mnie } \\
\text { do kupna pisma }\end{array}$ & & $\begin{array}{c}\text { Zniechęcają mnie do } \\
\text { przejrzenia pisma }\end{array}$ & & $\begin{array}{l}\text { Zniechęcają mnie } \\
\text { do kupna pisma }\end{array}$ \\
\hline Wulgarność & $6,0 \%$ & Erotyka & $5,1 \%$ & Wulgarnossć & $6,7 \%$ & Informacja & $4,3 \%$ & Kulinaria & $4,1 \%$ \\
\hline Erotyka & $12,1 \%$ & Wulgarność & $5,4 \%$ & Przemoc & $8,7 \%$ & Uroda & $4,8 \%$ & Inne & $7,1 \%$ \\
\hline Politycy i polityka & $12,6 \%$ & Gry komputerowe & $9,4 \%$ & Politycy i polityka & $8,9 \%$ & Poradnictwo & $5,6 \%$ & Moda & $7,3 \%$ \\
\hline $\begin{array}{c}\text { Gwiazdy } \\
\text { popkultury }\end{array}$ & $17,5 \%$ & Motoryzacja & $12,1 \%$ & Biznes i ekonomia & $13,5 \%$ & Kultura & $6,1 \%$ & $\begin{array}{c}\begin{array}{c}\text { Rodzicielstwo / } \\
\text { dzieci }\end{array} \\
\end{array}$ & $7,9 \%$ \\
\hline Nauka & $18,7 \%$ & Przemoc & $12,9 \%$ & Erotyka & $13,6 \%$ & Hobby & $7,4 \%$ & Uroda & $8,4 \%$ \\
\hline \multicolumn{10}{|c|}{ Pięć najbardziej licznych wskazań na poszczególne motywy - kobiety } \\
\hline & $\begin{array}{c}\text { Zwracają moją } \\
\text { uwagę }\end{array}$ & & $\begin{array}{c}\text { Zachęcają mnie do } \\
\text { przejrzenia pisma }\end{array}$ & & \begin{tabular}{|l|} 
Zachęcają mnie \\
do kupna pisma \\
\end{tabular} & & $\begin{array}{c}\text { Zniechęcają mnie do } \\
\text { przejrzenia pisma }\end{array}$ & & $\begin{array}{r}\text { Zniechęcają mnie } \\
\text { do kupna pisma }\end{array}$ \\
\hline Kulinaria & $27,2 \%$ & Historia & $32,2 \%$ & $\begin{array}{c}\begin{array}{c}\text { Historie z życia } \\
\text { wzięte }\end{array} \\
\end{array}$ & $28,7 \%$ & Przemoc & $30,5 \%$ & Gry komputerowe & $23,0 \%$ \\
\hline $\begin{array}{c}\text { Historie z życia } \\
\text { wzięte }\end{array}$ & $28,6 \%$ & Technologia & $32,6 \%$ & Hobby & $29,3 \%$ & Gry komputerowe & $32,9 \%$ & Politycy i polityka & $23,3 \%$ \\
\hline Hobby & $29,3 \%$ & Informacja & $32,9 \%$ & Informacja & $30,0 \%$ & Politycy i polityka & $41,1 \%$ & Przemoc & $23,4 \%$ \\
\hline Uroda & $31,6 \%$ & Kultura & $34,5 \%$ & Kulinaria & $31,0 \%$ & Erotyka & $42,1 \%$ & Erotyka & $27,1 \%$ \\
\hline Inne & $36,3 \%$ & Nauka & $35,7 \%$ & Poradnictwo & $32,2 \%$ & Wulgarność & $43,7 \%$ & Wulgarność & $38,3 \%$ \\
\hline
\end{tabular}

Tabela 2. Treść tematów okładkowych a kategoria demograficzna (płeć - kobiety). Źródło: opracowanie własne na podstawie badań przeprowadzonych na ogólnopolskiej próbie liczącej N=1094 osób, dobranej z panelu Ariadna metodą CAWI. Odpowiadający: wszyscy badani.

W przypadku mężczyzn (mowa o pozytywnym działaniu tematów okładkowych):

- uwagę w najmniejszym stopniu zwracają przemoc, wulgarność, politycy i polityka, publicystyka i religia; zaś w największym - gry komputerowe, informacja, hobby, erotyka i tzw. inne (nieujęte odrębnie);

- do przejrzenia pisma najmniej zachęcają wulgarność, moda, uroda, politycy i religia; zaś najbardziej - publicystyka, poradnictwo, nauka, historia, hobby;

- tematy okładkowe, które wpływają na zakup magazynów, to w najmniejszych stopniu wulgarność, przemoc, gwiazdy popkultury, politycy i polityka, erotyka; zaś w największym: publicystyka, tzw. inne, informacja, nauka i technologia. 
Biorąc pod uwagę negatywne oddziaływanie tematów okładkowych, zauważono, że:

- najrzadziej do przejrzenia pisma zniechęcają hobby, technologia, informacja, nauka i inne; najczęściej - uroda, gwiazdy popkultury, wulgarność, politycy i polityka, przemoc;

- do kupna demotywują najmniej technologia, nauka, informacja, poradnictwo, kultura i wulgarność, zaś najbardziej: uroda, politycy i polityka, moda, religia, wulgarność.

Do powtarzających się motywów w zakresie pozytywnego, acz najsłabszego, oddziaływania tematów okładkowych trzeba zaliczyć: przemoc, wulgarność, polityków i politykę, erotykę i religię. Najwięcej najlepszych odpowiedzi zyskały informacja, hobby, nauka. W negatywnym oddziaływaniu Polacy jako najmniej zniechęcające określili technologię, informację i naukę, zaś najbardziej - urodę, wulgarność, polityków i politykę. Odpowiedzi mężczyzn także wpisują się w stereotypowe ujęcie płci: wybierają erotykę (przy zwracaniu uwagi) lub technologię, ale także - tym razem negatywnie - urodę, gwiazdy popkultury i modę.

\begin{tabular}{|c|c|c|c|c|c|c|c|c|c|}
\hline \multicolumn{10}{|c|}{ Pięć najmniej licznych wskazań na poszzzególne motywy - mężczyźni } \\
\hline & $\begin{array}{c}\text { Zwracają } \\
\text { moją uwagę }\end{array}$ & & $\begin{array}{l}\text { Zachęcaja mnie do } \\
\text { przejrzenia pisma }\end{array}$ & & \begin{tabular}{|l|} 
Zachęcają mnie \\
do kupna pisma
\end{tabular} & & \begin{tabular}{|c|} 
Zniechęcają mnie do \\
przejrzenia pisma
\end{tabular} & & $\begin{array}{c}\begin{array}{c}\text { Zniechęcają mnie } \\
\text { do kupna pisma }\end{array} \\
\end{array}$ \\
\hline Przemoc & $11,4 \%$ & Wulgarność & $6,1 \%$ & Wulgarność & $10,4 \%$ & Hobby & $11,6 \%$ & Technologia & $3,2 \%$ \\
\hline Wulgarność & $13,2 \%$ & Moda & $10,0 \%$ & Przemoc & $13,3 \%$ & Technologia & $11,8 \%$ & Nauka & $6,6 \%$ \\
\hline Politycy i polityka & $15,3 \%$ & Uroda & $10,8 \%$ & $\begin{array}{c}\text { Gwiazdy } \\
\text { popkultury }\end{array}$ & $14,6 \%$ & Informacja & $12,0 \%$ & Informacja & $7,8 \%$ \\
\hline Publicystyka & $15,4 \%$ & Politycy i polityka & $11,0 \%$ & Politycy i polityka & $15,4 \%$ & Nauka & $13,0 \%$ & Poradnictwo & $8,4 \%$ \\
\hline Religia & $16,1 \%$ & Religia & $11,0 \%$ & Erotyka & $15,5 \%$ & Inne & $15,2 \%$ & Kultura & $8,7 \%$ \\
\hline \multicolumn{10}{|c|}{ Pięć najbardziej licznych wskazań na poszczególne motywy - mężczyźni } \\
\hline & $\begin{array}{c}\text { Zwracają } \\
\text { moją uwagę }\end{array}$ & & $\begin{array}{c}\text { Zachęcają mnie do } \\
\text { przejrzenia pisma }\end{array}$ & & \begin{tabular}{|l|} 
Zachęcają mnie \\
do kupna pisma
\end{tabular} & & $\begin{array}{c}\text { Zniechęcają mnie do } \\
\text { przejrzenia pisma }\end{array}$ & & $\begin{array}{c}\begin{array}{c}\text { Zniechęcają mnie } \\
\text { do kupna pisma }\end{array} \\
\end{array}$ \\
\hline Gry komputerowe & $26,0 \%$ & Publicystyka & $26,1 \%$ & Publicystyka & $27,5 \%$ & Uroda & $32,8 \%$ & Uroda & $18,6 \%$ \\
\hline Informacja & $26,7 \%$ & Poradnictwo & $26,2 \%$ & Inne & $29,7 \%$ & $\begin{array}{c}\text { Gwiazdy } \\
\text { popkultury }\end{array}$ & $33,0 \%$ & $\begin{array}{l}\text { Politycy i } \\
\text { polityka }\end{array}$ & $19,4 \%$ \\
\hline Hobby & $28,3 \%$ & Nauka & $27,1 \%$ & Informacja & $30,9 \%$ & Wulgarnośść & $38,6 \%$ & Moda & $19,7 \%$ \\
\hline Erotyka & $29,4 \%$ & Historia & $27,2 \%$ & Nauka & $32,7 \%$ & $\begin{array}{l}\text { Politycy i } \\
\text { polityka }\end{array}$ & $38,9 \%$ & Religia & $26,3 \%$ \\
\hline Inne & $29,8 \%$ & Hobby & $28,2 \%$ & Technologia & $37,0 \%$ & Przemoc & $44,4 \%$ & Wulgarność & $31,7 \%$ \\
\hline
\end{tabular}

Tabela 3. Treść tematów okładkowych a kategoria demograficzna (płeć - mężczyźni). Źródło: opracowanie własne na podstawie badań przeprowadzonych na ogólnopolskiej próbie liczącej N=1094 osób, dobranej z panelu Ariadna metodą CAWI. Odpowiadający: wszyscy badani.

Na podstawie powyższych danych można wysnuć następujący wniosek: otóż preferencje co do treści tematów okładkowych zmieniają się w zależności od płci, co zbiorczo przedstawia rysunek 1 (dla przejrzystości autorka zdecydowała się zaprezentować odpowiedzi dotyczące wyłącznie zachęcania przedstawicieli podgrup do kupna pisma). Panowie dużo lepiej niż panie oceniają technologię, publicystykę i motoryzację, ale też biznes i ekonomię, erotykę, gry komputerowe. Z większą ostrożnością od kobiet podchodzą do rodzicielstwa i dzieci, kulinariów, hobby, urody, mody i historii z życia wziętych ${ }^{3}$. Panie

3 Na przykład w badaniach Aleksandry Perchli-Włosik mężczyźni rzadziej przyznawali się do zainteresowań związanych z modą. Por. A. Perchla-Włosik, Młodzi mieszkańcy aglomeracji miejskich wobec mody 


\section{OBLICZA MEDIÓW I KOMUNIKACJI}

są nieco bardziej skłonne kupować pod wpływem gwiazd popkultury ${ }^{4}$. Z kolei, zarówno kobiety, jak i mężczyźni są dość zdystansowani do religii, a zdecydowanie negatywnie nastawieni do wulgarności, przemocy i polityków (chociaż panowie wykazują się w dwóch ostatnich przypadkach nieco większą tolerancją). Pozytywnie na obie płcie wpływa poradnictwo (tu z delikatnym wskazaniem na panie), a także wspomniana motoryzacja i publicystyka (ze znacznym wskazaniem na panów).

Płeć odbiorcy powinna zatem, zdaniem autorki, jednoznacznie wpływać na dobór treści tematów okładkowych, ponieważ - tak jak ich w przypadku innych produktów, niebędących mediami - przekłada się to na wyraźnie definiowalne reakcje konsumentów ${ }^{5}$.

\subsection{Wiek}

W najmłodszej grupie docelowej, w kontekście pozytywnego działania tematów okładkowych:

- uwagę w najmniejszym stopniu zwracają wulgarność, poradnictwo, motoryzacja, politycy i polityka, historia; zaś w największym - publicystyka, kultura, kulinaria, hobby i tzw. inne;

- do przejrzenia pisma najmniej zachęcają wulgarność, erotyka, przemoc, kulinaria, historie z życia wzięte; zaś najbardziej - biznes i ekonomia, sport, historia, technologia i nauka;

- tematy okładkowe, które wpływają na zakup magazynów, to w najmniejszym stopniu biznes i ekonomia, erotyka, politycy i polityka, gwiazdy popkultury i publicystyka; zaś w największym: kulinaria, moda, poradnictwo, historie z życia wzięte i informacja.

Z kolei, biorąc pod uwagę negatywne oddziaływanie tematów okładkowych, zauważono, że:

- najrzadziej do przejrzenia zniechęcają takie tematy jak hobby, technologia, nauka, inne, informacja; najczęściej - rodzicielstwo i dzieci, przemoc, politycy i polityka, wulgarność i erotyka;

- do kupna magazynu demotywują najmniej moda, rodzicielstwo i dzieci, kulinaria, inne i informacja; za to najbardziej - religia, gwiazdy popkultury, wulgarność, motoryzacja i gry komputerowe.

Wśród powtarzających się motywów w zakresie pozytywnego oddziaływania tematów okładkowych najsłabiej wypadły: wulgarność, politycy i polityka, erotyka, zaś

jako elementu stylu życia, „Handel Wewnętrzny” 2013, tom 1, s. 56.

4 Co w pewnym wiąże się z funkcjonującymi w społeczeństwie stereotypami płci oraz ich wykorzystywaniem przez marketing. Por. A. Rybowska, Stereotypy płci wyzwaniem dla marketingu, „Handel Wewnętrzny” 2013, tom 1, s. 98.

5 Na przykład wykazano, że „istnieje relacja między tożsamością płciową a reakcją konsumentów na marki” czy też zależność między „wpływem designu marki (kształtu logo, nazwy marki, czcionki i koloru) na postrzeganą męskość i kobiecość marki, preferencje konsumentów i kapitał marki”. Za: M. Hajdas, Wzorce męskości w komunikacji marki, „Uniwersytet Szczeciński - Zeszyty Naukowe nr 866, Problemy zarządzania, finansów i marketingu” 2015, (numer 39), s. 26. 
najlepiej: kulinaria. Jeśli zaś chodzi o negatywny wpływ tematów okładkowych na reakcje odbiorców, to powtarzają się (w zakresie najsłabszego działania) jedynie informacja i tzw. inne oraz (w zakresie najmocniejszego działania) - wulgarność.

Warto zwrócić uwagę na to, że na przykład publicystyka, która zwraca uwagę niemal 30\% respondentów, zachęca do kupna jedynie ok. 7\% (podobnie, jak biznes i ekonomia - pod ich wpływem magazyn przegląda ok. $27 \%$ badanych, ale kupuje - zaledwie ok. 4,5\%). A informacja? Co prawda zachęca do kupna ponad $32 \%$ odbiorców, lecz w tym samym czasie zniechęca do przejrzenia pisma niemal $25 \%$, a do kupna - prawie $13 \%$. Wydaje się, że dość dobrą pozycją cieszy się moda: pod jej wpływem kupuje 21\% Polaków (jedynie $4,3 \%$ jest nią zniechęconych). Najmłodsza grupa badanych wskazała kilka motywów sprzecznych z oczekiwaniem autorki. Otóż źle wypadły gry komputerowe i gwiazdy popkultury (zniechęcają do zakupu), zaś na wysokim miejscu znalazły się historie z życia wzięte (niemal 24\% czytelników kupuje pod ich wpływem). Najmłodsi respondenci kategorycznie odrzucili erotykę, pod wpływem której aż 59\% nie przegląda pisma.

\begin{tabular}{|c|c|c|c|c|c|c|c|c|c|}
\hline \multicolumn{10}{|c|}{ Pięć najmniej licznych wskazań na poszczególne motywy (18 - 24 lata) } \\
\hline & $\begin{array}{c}\text { Zwracają moja } \\
\text { uwage }\end{array}$ & & $\begin{array}{c}\text { Zachęcają mnie do } \\
\text { przejrzenia pisma }\end{array}$ & & $\begin{array}{c}\text { Zachęcają mnie do } \\
\text { kupna pisma }\end{array}$ & & $\begin{array}{c}\text { Zniechęcają mnie do } \\
\text { przejrzenia pisma }\end{array}$ & & \begin{tabular}{|c|}
$\begin{array}{c}\text { Zniechęcają mnie do } \\
\text { kupna pisma }\end{array}$ \\
\end{tabular} \\
\hline Wulgarność & $5,8 \%$ & Wulgarność & $2,7 \%$ & Bizmes i ekonomia & $4,6 \%$ & Hobby & $22,9 \%$ & Moda & $4,3 \%$ \\
\hline Poradnictwo & $7,1 \%$ & Erotyka & $2,9 \%$ & Erotyka & $4,8 \%$ & Technologia & $23,9 \%$ & $\begin{array}{c}\text { Rodzicielstwo / } \\
\text { dzieci }\end{array}$ & $5,8 \%$ \\
\hline Motoryzacja & $7,6 \%$ & Przemoc & $3,6 \%$ & Politycy i polityka & $6,0 \%$ & Nauka & $24,7 \%$ & Kulinaria & $10,0 \%$ \\
\hline Politycy i polityka & $8,9 \%$ & Kulinaria & $4,5 \%$ & $\begin{array}{c}\text { Gwiazdy } \\
\text { popkultury }\end{array}$ & $6,0 \%$ & Inne & $24,7 \%$ & Inne & $10,2 \%$ \\
\hline Historia & $10,3 \%$ & $\begin{array}{c}\text { Historie z życia } \\
\text { wzięte }\end{array}$ & $10,2 \%$ & Publicystyka & $7,2 \%$ & Informacja & $24,8 \%$ & Informacja & $12,6 \%$ \\
\hline \multicolumn{10}{|c|}{ Pięć najbardziej licznych wskazań na poszczególne motywy (18 - 24 lata) } \\
\hline & $\begin{array}{c}\text { Zwracają moją } \\
\text { uwag̨ }\end{array}$ & & $\begin{array}{c}\text { Zachęcają mnie do } \\
\text { przejrzenia pisma }\end{array}$ & & $\begin{array}{c}\text { Zachęcają mnie do } \\
\text { kupna pisma }\end{array}$ & & $\begin{array}{c}\text { Zniechęcają mnie do } \\
\text { przejrzenia pisma }\end{array}$ & & $\begin{array}{c}\text { Zniechęcają mnie do } \\
\text { kupna pisma }\end{array}$ \\
\hline Publicystyka & $29,6 \%$ & Biznes i ekonomia & $26,8 \%$ & Kulinaria & $20,3 \%$ & $\begin{array}{c}\text { Rodzicielstwo / } \\
\text { dzieci }\end{array}$ & $39,6 \%$ & Religia & $20,2 \%$ \\
\hline Kultura & $30,6 \%$ & Sport & $31,8 \%$ & Moda & $21,0 \%$ & Przemoc & $47,2 \%$ & $\begin{array}{c}\text { Gwiazdy } \\
\text { popkultury }\end{array}$ & $20,5 \%$ \\
\hline Kulinaria & $32,6 \%$ & Historia & $33,3 \%$ & Poradnictwo & $22,6 \%$ & Politycy i polityka & $50,6 \%$ & Wulgarność & $25,2 \%$ \\
\hline Hobby & $33,4 \%$ & Technologia & $34,1 \%$ & \begin{tabular}{|c|}
$\begin{array}{c}\text { Historie z życia } \\
\text { wzięte }\end{array}$ \\
\end{tabular} & $23,7 \%$ & Wulgarność & $54,3 \%$ & Motoryzacja & $29,9 \%$ \\
\hline Inne & $35,1 \%$ & Nauka & $38,9 \%$ & Informacja & $32,1 \%$ & Erotyka & $59,0 \%$ & Gry komputerowe & $30,2 \%$ \\
\hline
\end{tabular}

Tabela 4. Treść tematów okładkowych a kategoria demograficzna (wiek: 18 - 24 lata). Źródło: opracowanie własne na podstawie badań przeprowadzonych na ogólnopolskiej próbie liczącej N=1094 osób, dobranej z panelu Ariadna metodą CAWI. Odpowiadający: wszyscy badani.

W grupie docelowej (25-34 lata), w kontekście pozytywnego działania tematów:

- uwagę w najmniejszym stopniu zwracają historie z życia wzięte, sport, przemoc, poradnictwo i politycy i polityka; zaś w największym - gwiazdy popkultury, hobby, historia, uroda i tzw. inne;

- do przejrzenia pisma najmniej zachęcają wulgarność, religia, przemoc, erotyka i gry komputerowe; zaś najbardziej - hobby, kultura, nauka, historie z życia wzięte oraz poradnictwo;

- tematy okładkowe, które wpływają na zakup magazynów, to w najmniejszych stopniu wulgarność, przemoc, erotyka, religia i politycy i polityka; zaś w największym: informacja, hobby, nauka, technologia i kulinaria. 
Z kolei, biorąc pod uwagę negatywne oddziaływanie tematów okładkowych, dostrzeżono, że:

- najrzadziej do przejrzenia zniechęcają hobby, nauka, informacja, moda i kultura; najczęściej - politycy i polityka, sport, gry komputerowe, przemoc i wulgarność;

- do kupna magazynu demotywują najmniej technologia, kulinaria, nauka, hobby i poradnictwo; za to najbardziej - wulgarność, erotyka, przemoc, polityka i politycy i religia.

Wśród powtarzających się motywów w zakresie pozytywnego oddziaływania tematów okładkowych najsłabiej wypadły religia, erotyka, politycy i polityka, przemoc i wulgarność, zaś najlepiej: hobby i nauka. Jeśli chodzi o negatywny wpływ tematów okładkowych na reakcje odbiorców, to powtarzają się (w zakresie najsłabszego działania) jedynie hobby i nauka oraz (w zakresie najmocniejszego działania) - politycy i polityka, przemoc i wulgarność.

W opisanej grupie wiekowej można dostrzec większy niż poprzednio poziom zdecydowania: odpowiedzi powtarzają się i uzupełniają (np. to, co mało zniechęca do kupna jednocześnie do tego zachęca - tak jak we wskazaniach na temat technologii czy kulinariów). Badani wykazują ostrożny stosunek do religii, która nie dość, że ich nie zachęca do przejrzenia pisma (niecałe $10 \%$ odpowiedzi), to jeszcze demotywuje do jego kupna (34\% wskazań).

\begin{tabular}{|c|c|c|c|c|c|c|c|c|c|}
\hline \multicolumn{10}{|c|}{ Pięć najmniej licznych wskazań na poszzzególne motywy (25 - 34 lata) } \\
\hline & $\begin{array}{c}\text { Zwracają moja } \\
\text { uwage }\end{array}$ & & $\begin{array}{c}\text { Zachęcają mnie do } \\
\text { przejrzenia pisma }\end{array}$ & & $\begin{array}{c}\text { Zachęcają mnie do } \\
\text { kupna pisma }\end{array}$ & & $\begin{array}{c}\text { Zniechęcają minie } \\
\text { do przejrzenia } \\
\text { nisma }\end{array}$ & & $\begin{array}{c}\text { Zniechęcają mnie do } \\
\text { kupna pisma }\end{array}$ \\
\hline \begin{tabular}{|c}
$\begin{array}{c}\text { Historie z życia } \\
\text { wzięte }\end{array}$ \\
\end{tabular} & $13,1 \%$ & Wulgarność & $7,8 \%$ & Wulgarność & $12,1 \%$ & Hobby & $5,9 \%$ & Technologia & $7,3 \%$ \\
\hline Sport & $13,6 \%$ & Religia & $9,6 \%$ & Przemoc & $15,3 \%$ & Nauka & $8,3 \%$ & Kulinaria & $13,1 \%$ \\
\hline Przemoc & $14,0 \%$ & Przemoc & $9,7 \%$ & Erotyka & $16,2 \%$ & Informacja & $8,4 \%$ & Nauka & $13,7 \%$ \\
\hline Poradnictwo & $14,5 \%$ & Erotyka & $9,9 \%$ & Religia & $16,7 \%$ & Moda & $9,4 \%$ & Hobby & $13,9 \%$ \\
\hline Politycy i polityka & $14,6 \%$ & Gry komputerowe & $10,1 \%$ & Politycy i polityka & $18,2 \%$ & Kultura & $9,6 \%$ & Poradnictwo & $14,4 \%$ \\
\hline \multicolumn{10}{|c|}{ Pięć najbardziej licznych wskazań na poszczególne motywy (25 - 34 lata) } \\
\hline & $\begin{array}{c}\text { Zwracają moja } \\
\text { uwage }\end{array}$ & & $\begin{array}{c}\begin{array}{c}\text { Zachęcają mnie do } \\
\text { przejrzenia pisma }\end{array} \\
\end{array}$ & & $\begin{array}{c}\text { Zachęcają mnie do } \\
\text { kupna pisma }\end{array}$ & & $\begin{array}{c}\begin{array}{c}\text { Zniechęcają mnie } \\
\text { do przejrzenia } \\
\text { nisma }\end{array} \\
\end{array}$ & & $\begin{array}{c}\begin{array}{c}\text { Zniechęcają mnie do } \\
\text { kupna pisma }\end{array} \\
\end{array}$ \\
\hline $\begin{array}{c}\text { Gwiazdy } \\
\text { popkultury }\end{array}$ & $24,8 \%$ & Hobby & $21,7 \%$ & Informacja & $33,4 \%$ & Politycy i polityka & $28,0 \%$ & Wulgarność & $23,6 \%$ \\
\hline Hobby & $25,0 \%$ & Kultura & $24,4 \%$ & Hobby & $33,5 \%$ & Sport & $29,4 \%$ & Erotyka & $26,1 \%$ \\
\hline Historia & $26,8 \%$ & Nauka & $25,8 \%$ & Nauka & $34,7 \%$ & Gry komputerowe & $31,5 \%$ & Przemoc & $27,3 \%$ \\
\hline Uroda & $26,8 \%$ & $\begin{array}{c}\text { Historie } \mathbf{z} \text { życia } \\
\text { wzięte }\end{array}$ & $26,0 \%$ & Technologia & $35,0 \%$ & Przemoc & $33,7 \%$ & Politycy i polityka & $29,0 \%$ \\
\hline Inne & $32,9 \%$ & Poradnictwo & $28,5 \%$ & Kulinaria & $37,7 \%$ & Wulgarność & $36,5 \%$ & Religia & $34,1 \%$ \\
\hline
\end{tabular}

Tabela 5. Treść tematów okładkowych a kategoria demograficzna (wiek: 25-34 lata). Źródło: opracowanie własne na podstawie badań przeprowadzonych na ogólnopolskiej próbie liczącej N=1094 osób, dobranej z panelu Ariadna metodą CAWI. Odpowiadający: wszyscy badani.

W grupie docelowej (35-44 lata), w kontekście pozytywnego działania tematów:

- uwagę w najmniejszym stopniu zwracają takie motywy jak wulgarność, politycy i polityka, moda, motoryzacja i sport; zaś w największym - poradnictwo, gry komputerowe, rodzicielstwo/dzieci, erotyka i kulinaria; 

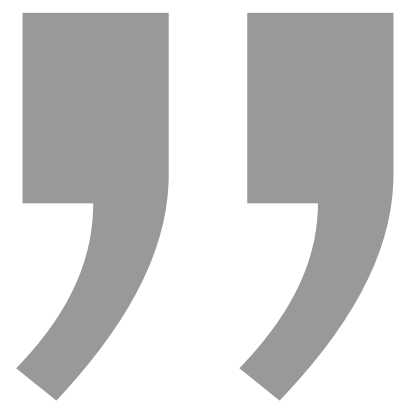

Warto zwrócić uwagę na to, że na przykład publicystyka, która zwraca uwagę niemal 30\% respondentów, zachęca do kupna jedynie ok. 7\% (podobnie, jak biznes i ekonomia - pod ich wpływem magazyn przegląda ok. 27\% badanych, ale kupuje - zaledwie ok. 4,5\%).

- do przejrzenia pisma najmniej zachęcają erotyka, gry komputerowe, sport, wulgarność, uroda; zaś najbardziej - poradnictwo, biznes i ekonomia, rodzicielstwo i dzieci, publicystyka i hobby;

- tematy okładkowe, które wpływają na zakup magazynów, to w najmniejszych stopniu wulgarność, politycy i polityka, przemoc, gwiazdy popkultury, biznes i ekonomia; zaś w największym: motoryzacja, informacja, inne, hobby, technologia i nauka.

Z kolei, biorąc pod uwagę negatywne oddziaływanie tematów okładkowych, zauważono, że:

- najrzadziej do przejrzenia zniechęcają takie tematy, jak hobby, nauka, informacja, technologia i poradnictwo; najczęściej - uroda, moda, gwiazdy popkultury, religia oraz politycy i polityka;

- do kupna magazynu demotywują najmniej tzw. inne, kulinaria, hobby, informacja i technologia; za to najbardziej - erotyka, motoryzacja, polityka i politycy, sport i wulgarność.

Wśród powtarzających się motywów w zakresie pozytywnego oddziaływania tematów okładkowych najsłabiej wypadły: sport, politycy i polityka, wulgarność, zaś najlepiej: poradnictwo oraz rodzicielstwo i dzieci. Jeśli zaś chodzi o negatywny wpływ tematów okładkowych na reakcje odbiorców, to powtarzają się (w zakresie najsłabszego działania) jedynie hobby, informacja, technologia i (w najmocniejszym działaniu) - politycy i polityka.

W tej grupie docelowej z pewnością można wskazać na zdecydowanie negatywnie oddziaływanie tematów politycznych, którzy najrzadziej zwracają uwagę i zachęcają do kupna oraz najbardziej zniechęcają do przejrzenia pisma (niemal 37\% wskazań). Polacy w wieku 35-44 lata częściej przy zakupie pisma kierują się tematami poważnymi takimi, jak nauka, technologia lub informacja. Raczej stronią od celebrytów, a nawet mody albo urody, natomiast ich zainteresowanie (ale już nie bezpośredni zakup) budzą motywy związane z rodzicielstwem i dziećmi oraz poradnictwem. 


\section{OBLICZA MEDIÓW I KOMUNIKACJI}

\begin{tabular}{|c|c|c|c|c|c|c|c|c|c|}
\hline \multicolumn{10}{|c|}{ Pięć najmniej licznych wskazań na poszczególne motywy (35 - 44 lata) } \\
\hline & $\begin{array}{c}\text { Zwracają moją } \\
\text { uwagę }\end{array}$ & & $\begin{array}{l}\text { Zachęcają mnie do } \\
\text { przejrzenia pisma }\end{array}$ & & $\begin{array}{c}\text { Zachęcają mnie do } \\
\text { kupna pisma }\end{array}$ & & $\begin{array}{c}\text { Zniechęcają mnie do } \\
\text { przejrzenia pisma }\end{array}$ & & $\begin{array}{l}\text { Zniechęcają mnie do } \\
\text { kupna pisma }\end{array}$ \\
\hline Wulgarność & $5,2 \%$ & Erotyka & $4,9 \%$ & Wulgarnośś & $10,7 \%$ & Hobby & $1,5 \%$ & Inne & $3,0 \%$ \\
\hline Politycy i polityka & $7,8 \%$ & Gry komputerowe & $8,0 \%$ & Politycy i polityka & $12,3 \%$ & Nauka & $2,6 \%$ & Kulinaria & $3,7 \%$ \\
\hline Moda & $10,8 \%$ & Sport & $8,2 \%$ & Przemoc & $13,0 \%$ & Informacja & $2,6 \%$ & Hobby & $11,3 \%$ \\
\hline Motoryzacja & $11,0 \%$ & Wulgarność & $10,5 \%$ & $\begin{array}{c}\text { Gwiazdy } \\
\text { popkultury }\end{array}$ & $15,2 \%$ & Technologia & $3,9 \%$ & Informacja & $11,5 \%$ \\
\hline Sport & $11,2 \%$ & Uroda & $12,3 \%$ & Biznes i ekonomia & $15,2 \%$ & Poradnictwo & $5,5 \%$ & Technologia & $11,8 \%$ \\
\hline \multicolumn{10}{|c|}{ Pięć najbardziej licznych wskazań na poszczególne motywy (35 - 44 lata) } \\
\hline & $\begin{array}{c}\text { Zwracają moją } \\
\text { uwagę }\end{array}$ & & $\begin{array}{l}\text { Zachęcają mnie do } \\
\text { przejrzenia pisma }\end{array}$ & & $\begin{array}{c}\text { Zachęcają mnie do } \\
\text { kupna pisma }\end{array}$ & & $\begin{array}{c}\text { Zniechęcają mnie do } \\
\text { przejrzenia pisma }\end{array}$ & & $\begin{array}{l}\text { Zniechęcają mnie do } \\
\text { kupna pisma }\end{array}$ \\
\hline Poradnictwo & $24,3 \%$ & Poradnictwo & $32,0 \%$ & Motoryzacja & $34,3 \%$ & Uroda & $28,2 \%$ & Erotyka & $27,6 \%$ \\
\hline Gry komputerowe & $27,2 \%$ & Biznes i ekonomia & $32,1 \%$ & Informacja & $38,2 \%$ & Moda & $28,2 \%$ & Motoryzacja & $27,7 \%$ \\
\hline $\begin{array}{c}\text { Rodzicielstwo / } \\
\text { dzieci }\end{array}$ & $29,2 \%$ & $\begin{array}{c}\text { Rodzicielstwo / } \\
\text { dzieci }\end{array}$ & $32,5 \%$ & Inne & $38,2 \%$ & $\begin{array}{c}\text { Gwiazdy } \\
\text { popkultury }\end{array}$ & $30,6 \%$ & Politycy i polityka & $30,0 \%$ \\
\hline Erotyka & $31,9 \%$ & Publicystyka & $32,8 \%$ & Technologia & $39,4 \%$ & Religia & $32,6 \%$ & Sport & $45,2 \%$ \\
\hline Kulinaria & $33,2 \%$ & Hobby & $37,7 \%$ & Nauka & $41,0 \%$ & Politycy i polityka & $36,7 \%$ & Wulgarność & $49,6 \%$ \\
\hline
\end{tabular}

Tabela 6. Treść tematów okładkowych a kategoria demograficzna (wiek: 35-44 lata). Źródło: opracowanie własne na podstawie badań przeprowadzonych na ogólnopolskiej próbie liczącej N=1094 osób, dobranej z panelu Ariadna metodą CAWI. Odpowiadający: wszyscy badani.

W kolejnej grupie docelowej (45-54 lata), w kontekście pozytywnego działania tematów okładkowych:

- uwagę w najmniejszym stopniu zwracają: wulgarność, religia, publicystyka, politycy i polityka, przemoc; zaś w największym - motoryzacja, inne, informacja, historie z życia wzięte oraz kultura;

- do przejrzenia pisma najmniej zachęcają wulgarność, politycy i polityka, gwiazdy popkultury, gry komputerowe i motoryzacja; zaś najbardziej - rodzicielstwo i dzieci, kulinaria, technologia, historia i religia;

- tematy okładkowe, które wpływają na zakup magazynów, to w najmniejszych stopniu wulgarność, przemoc, politycy i polityka, erotyka i religia; zaś w największym: uroda, inne, hobby, poradnictwo i nauka.

Z kolei, biorąc pod uwagę negatywne oddziaływanie tematów okładkowych zauważono, że:

- najrzadziej do przejrzenia zniechęcają informacja, inne, poradnictwo, historie z życia wzięte i kultura; najczęściej - gry komputerowe, erotyka, politycy i polityka, przemoc, wulgarność;

- do kupna magazynu demotywują najmniej informacja, poradnictwo, nauka, technologia i hobby; za to najbardziej - erotyka, religia, polityka i politycy, gry komputerowe i wulgarność.

Wśród powtarzających się motywów w zakresie pozytywnego oddziaływania tematów okładkowych najsłabiej wypadły przemoc, politycy i polityka, wulgarność, zaś najlepiej tylko kategoria „inne” (co wskazuje na duże rozproszenie gustów opisywanej grupy docelowej). Jeśli zaś chodzi o negatywny wpływ tematów okładkowych na reakcje 
odbiorców, to powtarzają się (w zakresie najsłabszego działania) jedynie informacja i poradnictwo oraz (w zakresie najmocniejszego działania) - gry komputerowe, erotyka, wulgarność oraz politycy i polityka.

Przy tej grupie łatwiej wskazać to, czego bardziej nie lubi, niż to, co preferuje. Tu Polacy zdecydowanie negatywnie oceniają gry komputerowe, które zniechęcają ich do kupna i przeglądania pisma. Ciekawie przedstawiają się wyniki związane z religią, która zniechęca do zakupu niemal 19\% badanych, ale ok. 16\% uznaje, że temat pozytywnie wpływa na ich decyzje zakupowe. Niezaprzeczalnie wysoko stoi zaś poradnictwo, które nie dość, że nie zniechęca, to jeszcze wpływa prosprzedażowo na decyzje odbiorców (prawie 38\% wskazań).

\begin{tabular}{|c|c|c|c|c|c|c|c|c|c|}
\hline \multicolumn{10}{|c|}{ Pięéc najmniej licznych wskazań na poszczególne motywy (45 - 54 lata) } \\
\hline & $\begin{array}{l}\text { Zwracają moją } \\
\text { uwagę }\end{array}$ & & $\begin{array}{l}\text { Zachęcają mnie do } \\
\text { przejrzenia pisma }\end{array}$ & & $\begin{array}{c}\text { Zachęcają mnie do } \\
\text { kupna pisma }\end{array}$ & & $\begin{array}{l}\text { Zniechęcają mnie do } \\
\text { przejrzenia pisma }\end{array}$ & & $\begin{array}{l}\text { Zniechęcają mnie do } \\
\text { kupna pisma }\end{array}$ \\
\hline Wulgarność & $9,0 \%$ & Wulgarność & $6,1 \%$ & Wulgarność & $9,5 \%$ & Informacja & $4,4 \%$ & Informacja & $4,7 \%$ \\
\hline Religia & $11,6 \%$ & Politycy i polityka & $9,3 \%$ & Przemoc & $10,0 \%$ & Inne & $4,4 \%$ & Poradnictwo & $5,7 \%$ \\
\hline Publicystyka & $14,0 \%$ & $\begin{array}{c}\text { Gwiazdy } \\
\text { popkultury }\end{array}$ & $12,0 \%$ & Politycy i polityka & $11,9 \%$ & Poradnictwo & $5,8 \%$ & Nauka & $6,5 \%$ \\
\hline Politycy i polityka & $14,2 \%$ & Gry komputerowe & $12,9 \%$ & Erotyka & $13,9 \%$ & $\begin{array}{c}\text { Historie z życia } \\
\text { wzięte }\end{array}$ & $9,5 \%$ & Technologia & $6,7 \%$ \\
\hline Przemoc & $14,3 \%$ & Motoryzacja & $14,0 \%$ & Religia & $16,3 \%$ & Kultura & $9,6 \%$ & Hobby & $6,9 \%$ \\
\hline \multicolumn{10}{|c|}{ Pięć najbardziej licznych wskazań na poszczególne motywy (45 - 54 lata) } \\
\hline & $\begin{array}{l}\text { Zwracają moją } \\
\text { uwagę }\end{array}$ & & $\begin{array}{l}\text { Zachęcają mnie do } \\
\text { przejrzenia pisma }\end{array}$ & & $\begin{array}{c}\text { Zachęcają mnie do } \\
\text { kupna pisma }\end{array}$ & & $\begin{array}{l}\text { Zniechęcają mnie do } \\
\text { przejrzenia pisma }\end{array}$ & & $\begin{array}{l}\text { Zniechęcają mnie do } \\
\text { kupna pisma }\end{array}$ \\
\hline Motoryzacja & $28,7 \%$ & $\begin{array}{c}\begin{array}{c}\text { Rodzicielstwo / } \\
\text { dzieci }\end{array} \\
\end{array}$ & $23,9 \%$ & Uroda & $36,5 \%$ & Gry komputerowe & $29,6 \%$ & Erotyka & $18,3 \%$ \\
\hline Inne & $30,9 \%$ & Kulinaria & $24,2 \%$ & Inne & $36,8 \%$ & Erotyka & $35,6 \%$ & Religia & $18,8 \%$ \\
\hline Informacja & $32,4 \%$ & Technologia & $24,3 \%$ & Hobby & $37,5 \%$ & Politycy i polityka & $43,7 \%$ & Politycy i polityka & $20,8 \%$ \\
\hline $\begin{array}{c}\text { Historie z życia } \\
\text { wziete }\end{array}$ & $32,9 \%$ & Historia & $24,5 \%$ & Poradnictwo & $37,6 \%$ & Przemoc & $43,9 \%$ & Gry komputerowe & $22,5 \%$ \\
\hline Kultura & $35,1 \%$ & Religia & $25,2 \%$ & Nauka & $40,3 \%$ & Wulgarność & $46,4 \%$ & Wulgarność & $29,1 \%$ \\
\hline
\end{tabular}

Tabela 7. Treść tematów okładkowych a kategoria demograficzna (wiek: 45-54 lata). Źródło: opracowanie własne na podstawie badań przeprowadzonych na ogólnopolskiej próbie liczącej N=1094 osób, dobranej z panelu Ariadna metodą CAWI. Odpowiadający: wszyscy badani.

W grupie docelowej (55 i więcej lat), w kontekście pozytywnego działania tematów:

- uwagę w najmniejszym stopniu zwracają wulgarność, erotyka, gwiazdy popkultury, politycy i polityka i publicystyka; zaś w największym - moda, kulinaria, uroda, hobby i inne;

- do przejrzenia pisma najmniej zachęcają wulgarność, gry komputerowe, przemoc, erotyka i politycy i polityka; zaś najbardziej historia, publicystyka, nauka, informacja, kultura;

- tematy okładkowe, które wpływają na zakup magazynów, to w najmniejszym stopniu wulgarność, przemoc, gry komputerowe, gwiazdy popkultury oraz politycy i polityka; zaś w największym: hobby, informacja, kulinaria, historie z życia wzięte, poradnictwo.

$\mathrm{Z}$ kolei, biorąc pod uwagę negatywne oddziaływanie tematów okładkowych dostrzeżono, że: 
- najrzadziej do przejrzenia zniechęcają informacja, poradnictwo, hobby, kultura i kulinaria; najczęściej - gwiazdy popkultury, przemoc, gry komputerowe, politycy i polityka, wulgarnośc;

- do kupna magazynu demotywują najmniej nauka, kultura, historia, informacja, poradnictwo; najbardziej - gry komputerowe, przemoc, religia, erotyka, religia i wulgarność.

Wśród powtarzających się motywów w zakresie pozytywnego oddziaływania tematów okładkowych najsłabiej wypadły erotyka, gwiazdy popkultury, przemoc, politycy i polityka, wulgarność, zaś najlepiej kulinaria, hobby i informacja. Jeśli chodzi o negatywny wpływ tematów okładkowych na reakcje odbiorców, to powtarzają się (w zakresie najsłabszego działania) kultura, informacja i poradnictwo oraz (w zakresie najmocniejszego działania) gry komputerowe, przemoc oraz wulgarność.

W tej grupie docelowej zdecydowanie źle wypadają gry komputerowe, które zniechęcają do przeglądania i kupowania pism, a motywy łączące się z szeroko rozumianym ogniskiem domowym zdecydowanie zyskują (np. poradnictwo, historie z życia wzięte czy kulinaria). Polacy cenią także informację (przeglądają i kupują pod jej wpływem), ignorują za to gwiazdy popkultury.

\begin{tabular}{|c|c|c|c|c|c|c|c|c|c|}
\hline \multicolumn{10}{|c|}{ Pięć najmniej licznych wskazań na poszczególne motywy (55 i więcej lat) } \\
\hline & $\begin{array}{c}\text { Zwracają moją } \\
\text { uwage }\end{array}$ & & $\begin{array}{l}\text { Zachęcają mnie do } \\
\text { przejrzenia pisma }\end{array}$ & & $\begin{array}{c}\text { Zachęcają mnie do } \\
\text { kupna pisma }\end{array}$ & & $\begin{array}{c}\text { Zniechęcają mnie do } \\
\text { przejrzenia pisma }\end{array}$ & & $\begin{array}{c}\text { Zniechęcają mnie } \\
\text { do kupna pisma }\end{array}$ \\
\hline Wulgarność & $6,6 \%$ & Wulgarność & $3,2 \%$ & Wulgarność & $2,8 \%$ & Informacja & $4,9 \%$ & Nauka & $1,4 \%$ \\
\hline Erotyka & $14,7 \%$ & Gry komputerowe & $10,7 \%$ & Przemoc & $8,7 \%$ & Poradnictwo & $7,6 \%$ & Kultura & $1,9 \%$ \\
\hline $\begin{array}{c}\text { Gwiazdy } \\
\text { popkultury }\end{array}$ & $16,4 \%$ & Przemoc & $11,9 \%$ & Gry komputerowe & $8,9 \%$ & Hobby & $8,5 \%$ & Historia & $2,1 \%$ \\
\hline Politycy i polityka & $18,6 \%$ & Erotyka & $13,2 \%$ & $\begin{array}{c}\text { Gwiazdy } \\
\text { popkultury }\end{array}$ & $9,6 \%$ & Kultura & $9,4 \%$ & Informacja & $2,7 \%$ \\
\hline Publicystyka & $19,5 \%$ & Politycy i polityka & $14,8 \%$ & Politycy i polityka & $10,6 \%$ & Kulinaria & $9,7 \%$ & Poradnictwo & $2,9 \%$ \\
\hline \multicolumn{10}{|c|}{ Pięć najbardziej licznych wskazań na poszczególne motywy ( 55 i więcej lat) } \\
\hline & $\begin{array}{c}\text { Zwracaja moją } \\
\text { uwage }\end{array}$ & & $\begin{array}{l}\text { Zachẹcają mnie do } \\
\text { przejrzenia pisma }\end{array}$ & & $\begin{array}{c}\text { Zachẹcaja mnie do } \\
\text { kupna pisma }\end{array}$ & & $\begin{array}{c}\text { Zniechęcaja mnie do } \\
\text { przejrzenia pisma }\end{array}$ & & $\begin{array}{l}\text { Zniechęcają mnie } \\
\text { do kupna pisma }\end{array}$ \\
\hline Moda & $31,5 \%$ & Historia & $39,7 \%$ & Hobby & $20,4 \%$ & $\begin{array}{c}\text { Gwiazdy } \\
\text { popkultury }\end{array}$ & $34,5 \%$ & Gry komputerowe & $14,7 \%$ \\
\hline Kulinaria & $31,6 \%$ & Publicystyka & $40,4 \%$ & Informacja & $21,2 \%$ & Przemoc & $37,0 \%$ & Przemoc & $20,2 \%$ \\
\hline Uroda & $32,0 \%$ & Nauka & $40,6 \%$ & Kulinaria & $23,0 \%$ & Gry komputerowe & $38,3 \%$ & Religia & $21,1 \%$ \\
\hline Hobby & $35,5 \%$ & Informacja & $40,8 \%$ & $\begin{array}{l}\text { Historie z życia } \\
\text { wzięte }\end{array}$ & $24,8 \%$ & Politycy i polityka & $42,7 \%$ & Erotyka & $25,4 \%$ \\
\hline Inne & $39,4 \%$ & Kultura & $47,3 \%$ & Poradnictwo & $26,9 \%$ & Wulgarność & $44,4 \%$ & Wulgarność & $43,1 \%$ \\
\hline
\end{tabular}

Tabela 8. Treść tematów okładkowych a kategoria demograficzna (wiek: 55+). Źródło: opracowanie własne na podstawie badań przeprowadzonych na ogólnopolskiej próbie liczącej N=1094 osób, dobranej z panelu Ariadna metodą CAWI. Odpowiadający: wszyscy badani.

Poza oczywistą niechęcią Polaków do wulgarności, przemocy oraz polityki i polityków, dane zmieniają się w zależności od podgrupy. I tak na przykład publicystyka czy nauka są preferowane przez grupy 25-34 i 35-54 lata, w znacznie mniejszym stopniu przez 55+, natomiast nie interesują zbytnio najmłodszych. Całkiem dobrze prosperują poradnictwo i historia, chociaż oczywiście pojawiają się różnice w poziomie wyników. Biznes i ekonomia nie wpływają na Polaków w wieku 18-24 lata, ale na grupy od 25 do 54 
lat już tak. Gry komputerowe najgorzej sprawują się wśród najmłodszych i najstarszych, zaś najlepiej wśród osób w wieku 35-44 lata. Gwiazdy popkultury i hobby to jedne z preferowanych motywów okładkowych przez osoby w wieku 45-54 lata. Informację najrzadziej wskazują ludzie powyżej 55 lat, zaś kulturę - Polacy do 24 roku życia. Kulinaria pełnią rolę prosprzedażową dla respondentów od 45 lat wzwyż, ale dla tych w wieku 18-44 lat - już nie. Z kolei technologia jest bardzo ważna dla wszystkich grup badanych poza najmłodszymi i najstarszymi. Jak widać na rysunku 2, różnic tych jest wiele, więc - aby dobrze wykorzystać otrzymane rezultaty, np. w aktywności biznesowej - należy kierować się sprecyzowanymi potrzebami każdej odrębnej grupy odbiorców.

\subsection{Wykształcenie}

Wyniki przeanalizowano przez pryzmat wykształcenia podstawowego, średniego, wyższego i zawodowego. W pierwszym przypadku (tabela 9), w związku z pozytywnym działaniem:

- uwagę w najmniejszym stopniu zwracają politycy i polityka, informacja, wulgarność, nauka i poradnictwo; zaś w największym: rodzicielstwo i dzieci, tzw. inne, hobby, gry komputerowe i kulinaria;

- do przejrzenia pisma najmniej zachęcają erotyka wulgarność, gry komputerowe, wulgarność, uroda oraz kulinaria; zaś najbardziej - publicystyka, nauka, poradnictwo, historia, biznes i ekonomia;

- tematy okładkowe, które wpływają na zakup magazynów, to w najmniejszych stopniu przemoc, wulgarność, historia, religia i kultura; zaś w największym: publicystyka, inne, nauka, technologia, informacja.

Z kolei, biorąc pod uwagę negatywne oddziaływanie tematów okładkowych, zauważono, że:

- najrzadziej do przejrzenia zniechęcają informacja, publicystyka, hobby, nauka i technologia; najczęściej - erotyka, gwiazdy popkultury, wulgarność, przemoc, politycy i polityka;

- do kupna magazynu demotywują najmniej kulinaria, inne, technologia, rodzicielstwo, moda; za to najbardziej - historie z życia wzięte, erotyka, motoryzacja, sport i wulgarność.

Wśród powtarzających się motywów w zakresie pozytywnego oddziaływania tematów okładkowych najsłabiej wypadła wulgarność, zaś najlepiej nauka i publicystyka. Jeśli chodzi o negatywny wpływ tematów na reakcje odbiorców, to powtarza się (w zakresie najsłabszego działania) technologia i (w zakresie najmocniejszego działania) - erotyka oraz wulgarność.

Osoby z wykształceniem podstawowym preferują publicystykę: temat ten w małym stopniu zniechęca je do przejrzenia pisma, za to zachęca i do przejrzenia (prawie $31 \%$ ), i do zakupu (prawie 22\%). Równie skuteczne może być eksponowanie informacji i nauki. Gry komputerowe, chociaż skutecznie zwracają uwagę odbiorców, to jednak nie 


\section{OBLICZA MEDIÓW I KOMUNIKACJI}

prowadzą do zakupu czy nawet przejrzenia magazynu (robi tak tylko 4,4\%). Warto zwrócić uwagę na słabą pozycję polityki (aż 55\% nie sięga po pismo z jej powodu) i gwiazd popkultury (35,6\% nie przegląda pod ich wpływem treści magazynu).

\begin{tabular}{|c|c|c|c|c|c|c|c|c|c|}
\hline \multicolumn{10}{|c|}{ Pięć najmniej licznych wskazań na poszczególne motywy (wyksztalcenie podstawowe) } \\
\hline & $\begin{array}{c}\text { Zwracają moją } \\
\text { uwagę }\end{array}$ & & $\begin{array}{l}\text { Zachęcają mnie do } \\
\text { przejrzenia pisma }\end{array}$ & & $\begin{array}{l}\text { Zachęcają mnie do } \\
\text { kupna pisma }\end{array}$ & & $\begin{array}{c}\text { Zniechęcają mnie do } \\
\text { przejrzenia pisma }\end{array}$ & & $\begin{array}{c}\text { Zniechęcają mnie do } \\
\text { kupna pisma }\end{array}$ \\
\hline $\begin{array}{c}\begin{array}{c}\text { Politycy i } \\
\text { polityka }\end{array} \\
\end{array}$ & $7,9 \%$ & Erotyka & $4,3 \%$ & Przemoc & $1,2 \%$ & Informacja & $10,4 \%$ & Kulinaria & $10,2 \%$ \\
\hline Informacja & $8,2 \%$ & $\begin{array}{c}\text { Gry } \\
\text { komputerowe }\end{array}$ & $4,4 \%$ & Wulgarność & $3,8 \%$ & Publicystyka & $10,4 \%$ & Inne & $10,2 \%$ \\
\hline Wulgarność & $8,7 \%$ & Wulgarność & $4,9 \%$ & Historia & $4,2 \%$ & Hobby & $10,4 \%$ & Technologia & $11,3 \%$ \\
\hline Nauka & $13,0 \%$ & Uroda & $11,3 \%$ & Religia & $4,2 \%$ & Nauka & $10,4 \%$ & $\begin{array}{c}\begin{array}{c}\text { Rodzicielstwo / } \\
\text { dzieci }\end{array} \\
\end{array}$ & $12,4 \%$ \\
\hline Poradnictwo & $16,1 \%$ & Kulinaria & $11,4 \%$ & Kultura & $6,1 \%$ & Technologia & $10,4 \%$ & Moda & $17,7 \%$ \\
\hline \multicolumn{10}{|c|}{ Pięć najbardziej licznych wskazań na poszczególne motywy (wyksztalcenie podstawowe) } \\
\hline & $\begin{array}{c}\text { Zwracają moją } \\
\text { uwage }\end{array}$ & & $\begin{array}{l}\text { Zachęcają mnie do } \\
\text { przejrzenia pisma }\end{array}$ & & $\begin{array}{l}\text { Zachęcają mnie do } \\
\text { kupna pisma }\end{array}$ & & $\begin{array}{l}\text { Zniechęcaja mnie do } \\
\text { przejrzenia pisma }\end{array}$ & & $\begin{array}{c}\text { Zniechęcają mnie do } \\
\text { kupna pisma }\end{array}$ \\
\hline $\begin{array}{c}\text { Rodzicielstwo / } \\
\text { dzieci }\end{array}$ & $33,4 \%$ & Publicystyka & $30,8 \%$ & Publicystyka & $21,6 \%$ & Erotyka & $34,2 \%$ & $\begin{array}{c}\begin{array}{c}\text { Historie z żcia } \\
\text { wzięte }\end{array} \\
\end{array}$ & $30,9 \%$ \\
\hline Inne & $33,6 \%$ & Nauka & $31,0 \%$ & Inne & $26,4 \%$ & $\begin{array}{c}\text { Gwiazdy } \\
\text { popkultury }\end{array}$ & $35,6 \%$ & Erotyka & $31,1 \%$ \\
\hline Hobby & $34,4 \%$ & Poradnictwo & $33,2 \%$ & Nauka & $27,8 \%$ & Wulgarność & $42,6 \%$ & Motoryzacja & $31,9 \%$ \\
\hline $\begin{array}{c}\text { Gry } \\
\text { komputerowe }\end{array}$ & $36,4 \%$ & Historia & $34,1 \%$ & Technologia & $29,8 \%$ & Przemoc & $44,6 \%$ & Sport & $36,1 \%$ \\
\hline Kulinaria & $39,1 \%$ & $\begin{array}{c}\text { Biznes i } \\
\text { ekonomia }\end{array}$ & $35,3 \%$ & Informacja & $37,8 \%$ & $\begin{array}{c}\begin{array}{c}\text { Politycy i } \\
\text { polityka }\end{array} \\
\end{array}$ & $55,0 \%$ & Wulgarność & $40,1 \%$ \\
\hline
\end{tabular}

Tabela 9. Treść tematów okładkowych a kategoria demograficzna (wykształcenie podstawowe). Źródło: opracowanie własne na podstawie badań przeprowadzonych na ogólnopolskiej próbie liczącej N=1094 osób, dobranej z panelu Ariadna metodą CAWI. Odpowiadający: wszyscy badani.

W przypadku osób ze średnim wykształceniem (tabela 10) w związku z pozytywnym działaniem tematów okładkowych:

- uwagę w najmniejszym stopniu zwracają wulgarność, politycy i polityka, przemoc, erotyka i gry komputerowe; zaś w największym: sport, hobby, poradnictwo, informacja i tzw. inne;

- do przejrzenia pisma najmniej zachęcają wulgarność, przemoc, erotyka, politycy i polityka oraz religia; zaś najbardziej - historia, kultura, informacja, technologia, nauka;

- tematy okładkowe, które wpływają na zakup magazynów, to w najmniejszych stopniu wulgarność, przemoc, politycy i polityka, erotyka i religia; zaś w największym: rodzicielstwo i dzieci, kulinaria, historie z życia wzięte, uroda i poradnictwo.

Biorąc pod uwagę negatywne oddziaływanie tematów okładkowych, dostrzeżono, że:

- najrzadziej do przejrzenia zniechęcają takie tematy jak informacja, hobby, poradnictwo, nauka i kultura; najczęściej - erotyka, gry komputerowe, przemoc, politycy i polityka oraz wulgarność;

- do kupna magazynu demotywują najmniej nauka, informacja, poradnictwo, inne, technologia; najbardziej - politycy i polityka, religia, erotyka, przemoc i wulgarność. 
Wśród powtarzających się motywów w zakresie pozytywnego oddziaływania tematów okładkowych najsłabiej wypadły wulgarność, politycy i polityka, przemoc, erotyka i religia; zaś najlepiej poradnictwo i informacja. Jeśli chodzi o negatywny wpływ tematów okładkowych na reakcje odbiorców, to powtarzają się (w zakresie najsłabszego działania) informacja, poradnictwo i nauka oraz (w zakresie najmocniejszego działania) - przemoc, politycy i polityka, erotyka oraz wulgarność. Opisywana grupa z pewnością wie, czego nie lubi - wskazując na motywy, które jednocześnie najsłabiej zwracają jej uwagę, zachęcają do przeglądania do kupna i tym samym zniechęcają do przeglądania i zakupu. Są to wulgarność, przemoc, politycy i polityka oraz erotyka. Polacy o średnim wykształceniu pozostają niemal jednomyślni, zatem wydawcy, kierując do nich ofertę, powinni mieć to na względzie. Z kolei, dobrze odbierane jest poradnictwo: zwraca ono uwagę i zachęca do zakupu pisma (raczej bez uprzedniego przeglądania): można stwierdzić, że ten motyw prowokuje zakup spontaniczny.

\begin{tabular}{|c|c|c|c|c|c|c|c|c|c|}
\hline \multicolumn{10}{|c|}{ Pięć najmniej licznych wskazań na poszczególne motywy (wyksztalcenie średnie) } \\
\hline & $\begin{array}{c}\text { Zwracają moją } \\
\text { uwagę }\end{array}$ & & $\begin{array}{l}\text { Zachęcają mnie do } \\
\text { przejrzenia pisma }\end{array}$ & & $\begin{array}{l}\text { Zachęcają mnie do } \\
\text { kupna pisma }\end{array}$ & & $\begin{array}{l}\text { Zniechęcają mnie do } \\
\text { przejrzenia pisma }\end{array}$ & & $\begin{array}{c}\text { Zniechęcają mnie do } \\
\text { kupna pisma }\end{array}$ \\
\hline Wulgarnośś & $8,7 \%$ & Wulgarność & $4,8 \%$ & Wulgarność & $7,4 \%$ & Informacja & $7,1 \%$ & Nauka & $4,1 \%$ \\
\hline $\begin{array}{l}\begin{array}{c}\text { Politycy i } \\
\text { polityka }\end{array} \\
\end{array}$ & $15,8 \%$ & Przemoc & $13,2 \%$ & Przemoc & $13,4 \%$ & Hobby & $9,1 \%$ & Informacja & $4,4 \%$ \\
\hline Przemoc & $16,3 \%$ & Erotyka & $13,6 \%$ & $\begin{array}{c}\text { Politycy i } \\
\text { polityka }\end{array}$ & $14,5 \%$ & Poradnictwo & $9,7 \%$ & Poradnictwo & $4,7 \%$ \\
\hline Erotyka & $16,9 \%$ & $\begin{array}{c}\text { Politycy i } \\
\text { polityka }\end{array}$ & $14,0 \%$ & Erotyka & $15,2 \%$ & Nauka & $10,2 \%$ & Inne & $5,2 \%$ \\
\hline $\begin{array}{c}\text { Gry } \\
\text { komputerowe }\end{array}$ & $17,6 \%$ & Religia & $16,2 \%$ & Religia & $15,5 \%$ & Kultura & $12,3 \%$ & Technologia & $5,2 \%$ \\
\hline \multicolumn{10}{|c|}{ Pięć najbardziej licznych wskazań na poszzzególne motywy (wyksztalcenie średnie) } \\
\hline & $\begin{array}{c}\text { Zwracają moją } \\
\text { uwagę }\end{array}$ & & $\begin{array}{l}\text { Zachęcaja mnie do } \\
\text { przejrzenia pisma }\end{array}$ & & $\begin{array}{l}\text { Zachęcają mnie do } \\
\text { kupna pisma }\end{array}$ & & $\begin{array}{l}\text { Zniechęcają mnie do } \\
\text { przejrzenia pisma }\end{array}$ & & $\begin{array}{c}\text { Zniechęcają mnie do } \\
\text { kupna pisma }\end{array}$ \\
\hline Sport & $23,6 \%$ & Historia & $31,9 \%$ & $\begin{array}{c}\text { Rodzicielstwo / } \\
\text { dzieci }\end{array}$ & $26,7 \%$ & Erotyka & $31,7 \%$ & $\begin{array}{c}\begin{array}{c}\text { Politycy i } \\
\text { polityka }\end{array} \\
\end{array}$ & $18,7 \%$ \\
\hline Hobby & $27,4 \%$ & Kultura & $32,1 \%$ & Kulinaria & $28,1 \%$ & $\begin{array}{c}\text { Gry } \\
\text { komputerowe }\end{array}$ & $32,2 \%$ & Religia & $22,2 \%$ \\
\hline Poradnictwo & $27,7 \%$ & Informacja & $33,4 \%$ & $\begin{array}{c}\text { Historie z życia } \\
\text { wzięte }\end{array}$ & $28,3 \%$ & Przemoc & $33,2 \%$ & Erotyka & $22,6 \%$ \\
\hline Informacja & $29,6 \%$ & Technologia & $34,6 \%$ & Uroda & $28,8 \%$ & $\begin{array}{c}\begin{array}{c}\text { Politycy i } \\
\text { polityka }\end{array} \\
\end{array}$ & $37,0 \%$ & Przemoc & $23,9 \%$ \\
\hline Inne & $31,5 \%$ & Nauka & $36,1 \%$ & Poradnictwo & $29,5 \%$ & Wulgarność & $43,4 \%$ & Wulgarność & $35,7 \%$ \\
\hline
\end{tabular}

Tabela 10. Treść tematów okładkowych a kategoria demograficzna (wykształcenie średnie). Źródło: opracowanie własne na podstawie badań przeprowadzonych na ogólnopolskiej próbie liczącej N=1094 osób, dobranej z panelu Ariadna metodą CAWI. Odpowiadający: wszyscy badani.

W przypadku osób z wyższym wykształceniem (tabela 11), w związku z pozytywnym działaniem tematów okładkowych:

- uwage w najmniejszym stopniu zwracają wulgarność, przemoc, erotyka, religia i politycy i polityka; zaś w największym: kulinaria, kultura, hobby, informacja i inne;

- do przejrzenia pisma najmniej zachęcają wulgarność, przemoc, gry komputerowe, erotyka, politycy i polityka; zaś najbardziej - biznes i ekonomia, technologia, kultura, historia i nauka;

- tematy okładkowe, które wpływają na zakup magazynów, to w najmniejszych stopniu wulgarność, przemoc, politycy i polityka, gry komputerowe i erotyka; zaś w największym: kulinaria, informacja, nauka, poradnictwo i hobby. 
Biorąc pod uwagę negatywne oddziaływanie tematów okładkowych, zauważono, że:

- najrzadziej do przejrzenia zniechęcają hobby, informacja, nauka, kultura i poradnictwo; najczęściej - gry komputerowe, politycy i polityka, erotyka, wulgarność i przemoc;

- do kupna magazynu demotywują najmniej nauka, kultura, hobby, informacja, historia; za to najbardziej - religia, politycy i polityka, gry komputerowe, przemoc i wulgarność.

Wśród powtarzających się motywów w zakresie pozytywnego oddziaływania tematów okładkowych najsłabiej wypadły wulgarność, politycy i polityka, przemoc, erotyka i gry komputerowe; zaś najlepiej kulinaria, kultura, hobby, informacja i nauka. Jeśli chodzi o negatywny wpływ tematów okładkowych na reakcje odbiorców, to powtarzają się (w zakresie najsłabszego działania) informacja, hobby, kultura i nauka oraz (w zakresie najmocniejszego działania) - przemoc, politycy i polityka, gry komputerowe oraz wulgarność.

Także i ta grupa docelowa wykazuje się dużym zdecydowania, odrzucając takie motywy jak przemoc, wulgarność, politykę, erotykę oraz... gry komputerowe. Te ostatnie właściwie nie zachęcają respondentów do przejrzenia i kupna pisma, co więcej: są silnym czynnikiem demotywującym (ponad 31\% nie przegląda magazynów pod ich wpływem, a nie kupuje - prawie 23\%). Problematyczna jest także religia - zwraca na nią uwagę niemal 18\% Polaków z wyższym wykształceniem, ale nie kupuje z jej powodu prawie $22 \%$. Zgodnie z oczekiwaniami, na dobrych pozycjach znajdują się tematy takie, jak nauka (która zachęca i do przeglądania treści, i do kupowania pisma) czy informacja (ta z kolei zwraca uwagę i zachęca do kupna). Badani cenią także kulturę - co prawda nie pojawia się ona w zestawieniu motywów najbardziej zachęcających do zakupu, ale temat ten z pewnością nie zniechęca, a po drugie - zwraca uwagę i przyczynia się do przeglądania magazynu.

\begin{tabular}{|c|c|c|c|c|c|c|c|c|c|}
\hline \multicolumn{10}{|c|}{ Pięć najmniej licznych wskazań na poszczególne motywy (wyksztalcenie wyżzze) } \\
\hline & $\begin{array}{c}\text { Zwracają moją } \\
\text { uwage }\end{array}$ & & $\begin{array}{l}\text { Zachęcają mnie do } \\
\text { przejrzenia pisma }\end{array}$ & & $\begin{array}{l}\text { Zachęcają mnie } \\
\text { do kupna pisma }\end{array}$ & & $\begin{array}{l}\text { Zniechęcają mnie do } \\
\text { przejrzenia pisma }\end{array}$ & & $\begin{array}{c}\text { Zniechęcają mnie do } \\
\text { kupna pisma }\end{array}$ \\
\hline Wulgarność & $10,8 \%$ & Wulgarność & $6,1 \%$ & Wulgarność & $6,4 \%$ & Hobby & $6,7 \%$ & Nauka & $3,6 \%$ \\
\hline Przemoc & $17,4 \%$ & Przemoc & $8,0 \%$ & Przemoc & $10,5 \%$ & Informacja & $7,2 \%$ & Kultura & $5,1 \%$ \\
\hline Erotyka & $17,8 \%$ & $\begin{array}{c}\begin{array}{c}\text { Gry } \\
\text { komputerowe }\end{array} \\
\end{array}$ & $11,7 \%$ & $\begin{array}{c}\text { Politycy i } \\
\text { polityka }\end{array}$ & $13,5 \%$ & Nauka & $7,8 \%$ & Hobby & $5,1 \%$ \\
\hline Religia & $17,9 \%$ & Erotyka & $13,3 \%$ & $\begin{array}{c}\text { Gry } \\
\text { komputerowe }\end{array}$ & $14,3 \%$ & Kultura & $11,3 \%$ & Informacja & $5,2 \%$ \\
\hline $\begin{array}{c}\begin{array}{c}\text { Politycy i } \\
\text { polityka }\end{array} \\
\end{array}$ & $17,9 \%$ & $\begin{array}{c}\begin{array}{c}\text { Politycy i } \\
\text { polityka }\end{array} \\
\end{array}$ & $14,7 \%$ & Erotyka & $14,7 \%$ & Poradnictwo & $12,9 \%$ & Historia & $7,2 \%$ \\
\hline
\end{tabular}

\begin{tabular}{|c|c|c|c|c|c|c|c|c|c|}
\hline \multicolumn{10}{|c|}{ Pięć najbardziej licznych wskazań na poszczególne motywy (wykszalcenie wyżzze) } \\
\hline & $\begin{array}{c}\text { Zwracają moją } \\
\text { uwagę }\end{array}$ & & $\begin{array}{l}\text { Zachęcają mnie do } \\
\text { przejrzenia pisma }\end{array}$ & & $\begin{array}{r}\text { Zachęcają mnie } \\
\text { do kupna pisma }\end{array}$ & & $\begin{array}{c}\text { Zniechęcają mnie do } \\
\text { przejrzenia pisma }\end{array}$ & & $\begin{array}{c}\text { Zniechęcają mnie do } \\
\text { kupna pisma }\end{array}$ \\
\hline Kulinaria & $25,9 \%$ & $\begin{array}{c}\text { Biznes i } \\
\text { ekonomia }\end{array}$ & $31,2 \%$ & Kulinaria & $27,4 \%$ & $\begin{array}{c}\text { Gry } \\
\text { komputerowe }\end{array}$ & $31,5 \%$ & Religia & $21,7 \%$ \\
\hline Kultura & $27,0 \%$ & Technologia & $32,9 \%$ & Informacja & $28,3 \%$ & $\begin{array}{c}\text { Politycy i } \\
\text { polityka }\end{array}$ & $31,7 \%$ & $\begin{array}{c}\text { Politycy i } \\
\text { polityka }\end{array}$ & $22,2 \%$ \\
\hline Hobby & $27,5 \%$ & Kultura & $34,5 \%$ & Nauka & $28,7 \%$ & Erotyka & $35,1 \%$ & $\begin{array}{c}\text { Gry } \\
\text { komputerowe }\end{array}$ & $22,9 \%$ \\
\hline Informacja & $32,7 \%$ & Historia & $34,6 \%$ & Poradnictwo & $29,2 \%$ & Wulgarność & $36,0 \%$ & Przemoc & $27,7 \%$ \\
\hline Inne & $35,7 \%$ & Nauka & $35,8 \%$ & Hobby & $30,2 \%$ & Przemoc & $36,5 \%$ & Wulgarność & $40,7 \%$ \\
\hline
\end{tabular}

Tabela 11. Treść tematów okładkowych a kategoria demograficzna (wykształcenie wyższe). Źródło: opracowanie własne na podstawie badań przeprowadzonych na ogólnopolskiej próbie liczącej N=1094 osób, dobranej z panelu Ariadna metodą CAWI. Odpowiadający: wszyscy badani. 
W przypadku osób z zawodowym wykształceniem, w związku z pozytywnym działaniem tematów okładkowych:

- uwagę w najmniejszym stopniu zwracają wulgarność, sport, religia i politycy i polityka oraz kulinaria; zaś w największym: hobby, moda, uroda, informacja i tzw. inne;

- do przejrzenia pisma najmniej zachęcają wulgarność, politycy i polityka, gry komputerowe, erotyka i religia; zaś najbardziej - poradnictwo, technologia, kulinaria, kultura, rodzicielstwo i dzieci;

- tematy okładkowe, które wpływają na zakup magazynów, to w najmniejszych stopniu wulgarność, przemoc, politycy i polityka, erotyka i gry komputerowe; w największym: motoryzacja, kulinaria, informacja, hobby, poradnictwo i historie z życia wzięte.

Z kolei, biorąc pod uwagę negatywne oddziaływanie tematów okładkowych, zauważono, że:

- najrzadziej do przejrzenia zniechęcają historie z życia wzięte, informacja, poradnictwo, kultura i hobby; najczęściej - publicystyka, gry komputerowe, politycy i polityka, przemoc i wulgarność;

- do kupna magazynu demotywują najmniej poradnictwo, hobby, historie z życia wzięte, nauka i technologia; za to najbardziej - erotyka, gry komputerowe, religia, politycy i polityka i wulgarność.

Wśród powtarzających się motywów w zakresie pozytywnego oddziaływania tematów okładkowych najsłabiej wypadły wulgarność, politycy i polityka, religia, erotyka i gry komputerowe; zaś najlepiej kulinaria, hobby i poradnictwo. Jeśli chodzi o negatywny wpływ tematów okładkowych na reakcje odbiorców, to powtarzają się (w zakresie najsłabszego działania) i historie z życia wzięte, poradnictwo i hobby oraz (w zakresie najmocniejszego działania) - politycy i polityka, gry komputerowe i wulgarność.

W przypadku Polaków z wykształceniem zawodowym do przeglądania i kupna zachęcają tematy bliższe codziennemu życiu, tj. poradnictwo, kulinaria, historie z życia wzięte lub rodzicielstwo. Grupa ta z pewnością nie preferuje wulgarności oraz polityków i polityki, ale na przykład przemoc - tak krytycznie oceniania przez pozostałych respondentów - tu nie demotywuje tak bardzo do zakupu (co ciekawe, ponad 19\% badanych twierdzi, że przemoc zachęca ich do nabycia pisma). Równie interesujące są wskazania na erotykę: $17 \%$ badanych z jej powodów nie kupiłoby magazynu, ale ok. $22 \%$ już tak.

Także i przy wykształceniu Polaków widać wyraźnie różnice między odpowiedziami poszczególnych podgrup (zbiorcze przedstawienie na rysunku 3). Na przykład tematy kulinariów, motoryzacji, historii z życia wziętych czy celebrytów preferują osoby z wykształceniem zawodowym, a najmniej są na niego podatni absolwenci szkół podstawowych. Ci ostatni kupują pod wpływem informacji, uzyskując najlepsze wyniki ze wszystkich grup bada- 


\section{OBLICZA MEDIÓW I KOMUNIKACJI}

nych. Interesująca dla nich jest również technologia: ich wyniki zrównują się lub przewyższają odpowiedzi pozostałych respondentów. Polacy po szkole podstawowej nie ulegają historii, biznesowi, kulturze i religii - to motywy, które zyskują tu najniższe notowania. Z kolei, odpowiedzi osób z wykształceniem średnim i wyższym są zbliżone ${ }^{6}$ - istotne różnice pojawiają się głównie przy takich tematach, jak historie z życia wzięte, moda, sport czy uroda (preferują je Polacy po szkole średniej). Respondenci po studiach nieco częściej kupują pod wpływem hobby i informacji oraz (w niewielkim stopniu) publicystyki.

\begin{tabular}{|c|c|c|c|c|c|c|c|c|c|}
\hline \multicolumn{10}{|c|}{ Pięć najmniej licznych wskazań na poszczególne motywy (wyksztalcenie zawodowe) } \\
\hline & $\begin{array}{c}\text { Zwracają moją } \\
\text { uwagę }\end{array}$ & & $\begin{array}{c}\text { Zachęcają mnie do } \\
\text { przejrzenia pisma }\end{array}$ & & $\begin{array}{l}\text { Zachęcają mnie do } \\
\text { kupna pisma }\end{array}$ & & $\begin{array}{c}\text { Zniechęcają mnie do } \\
\text { przejrzenia pisma }\end{array}$ & & $\begin{array}{c}\text { Zniechęcają mnie } \\
\text { do kupna pisma }\end{array}$ \\
\hline Wulgarność & $10,1 \%$ & Wulgarność & $8,0 \%$ & Wulgarność & $17,3 \%$ & $\begin{array}{c}\text { Historie z życia } \\
\text { wzięte }\end{array}$ & $5,8 \%$ & Poradnictwo & $4,2 \%$ \\
\hline Sport & $13,2 \%$ & $\begin{array}{l}\text { Politycy i } \\
\text { polityka }\end{array}$ & $8,5 \%$ & Przemoc & $19,2 \%$ & Informacja & $6,8 \%$ & Hobby & $5,1 \%$ \\
\hline Religia & $14,4 \%$ & $\begin{array}{c}\text { Gry } \\
\text { komputerowe }\end{array}$ & $9,2 \%$ & $\begin{array}{c}\begin{array}{c}\text { Politycy i } \\
\text { polityka }\end{array} \\
\end{array}$ & $21,7 \%$ & Poradnictwo & $8,0 \%$ & \begin{tabular}{|c}
$\begin{array}{c}\text { Historie z życia } \\
\text { wzięte }\end{array}$ \\
\end{tabular} & $5,4 \%$ \\
\hline $\begin{array}{l}\text { Politycy i } \\
\text { polityka }\end{array}$ & $15,3 \%$ & Erotyka & $9,6 \%$ & Erotyka & $22,2 \%$ & Kultura & $10,6 \%$ & Nauka & $6,1 \%$ \\
\hline Kulinaria & $15,6 \%$ & Religia & $13,3 \%$ & $\begin{array}{c}\text { Gry } \\
\text { komputerowe }\end{array}$ & $24,2 \%$ & Hobby & $10,9 \%$ & Technologia & $6,8 \%$ \\
\hline
\end{tabular}

\begin{tabular}{|c|c|c|c|c|c|c|c|c|c|}
\hline \multicolumn{10}{|c|}{ Pięć najbardziej licznych wskazań na poszczególne motywy (wyksztalcenie zawodowe } \\
\hline & $\begin{array}{c}\text { Zwracają moją } \\
\text { uwagę }\end{array}$ & & $\begin{array}{c}\text { Zachęcają mnie do } \\
\text { przejrzenia pisma }\end{array}$ & & $\begin{array}{l}\text { Zachęcają mnie do } \\
\text { kupna pisma }\end{array}$ & & $\begin{array}{c}\text { Zniechęcają mnie do } \\
\text { przejrzenia pisma }\end{array}$ & & $\begin{array}{c}\text { Zniechęcają mnie } \\
\text { do kupna pisma }\end{array}$ \\
\hline Hobby & $25,2 \%$ & Poradnictwo & $24,9 \%$ & Motoryzacja & $33,9 \%$ & Publicystyka & $28,4 \%$ & Erotyka & $17,0 \%$ \\
\hline Moda & $25,7 \%$ & Technologia & $27,4 \%$ & Kulinaria & $34,9 \%$ & $\begin{array}{c}\text { Gry } \\
\text { komputerowe }\end{array}$ & $29,1 \%$ & $\begin{array}{c}\text { Gry } \\
\text { komputerowe }\end{array}$ & $19,1 \%$ \\
\hline Uroda & $26,3 \%$ & Kulinaria & $28,6 \%$ & Hobby & $36,4 \%$ & $\begin{array}{c}\begin{array}{c}\text { Politycy i } \\
\text { polityka }\end{array} \\
\end{array}$ & $33,1 \%$ & Religia & $21,4 \%$ \\
\hline Informacja & $31,5 \%$ & Kultura & $28,8 \%$ & Poradnictwo & $40,5 \%$ & Przemoc & $34,3 \%$ & $\begin{array}{c}\text { Politycy i } \\
\text { polityka }\end{array}$ & $21,4 \%$ \\
\hline Inne & $33,4 \%$ & $\begin{array}{c}\text { Rodzicielstwo / } \\
\text { dzieci }\end{array}$ & $32,0 \%$ & $\begin{array}{c}\text { Historie z życia } \\
\text { wzięte }\end{array}$ & $45,4 \%$ & Wulgarność & $40,7 \%$ & Wulgarność & $23,9 \%$ \\
\hline
\end{tabular}

Tabela 12. Treść tematów okładkowych a kategoria demograficzna (wykształcenie zawodowe). Źródło: opracowanie własne na podstawie badań przeprowadzonych na ogólnopolskiej próbie liczącej N=1094 osób, dobranej z panelu Ariadna metodą CAWI. Odpowiadający: wszyscy badani.

Są tematy, których odbiorcy wspólnie nie preferują. Zaliczają się do nich politycy i polityka, przemoc i wulgarność (a poza osobami po szkole zawodowej - dodatkowo religia, sport i wspomniana motoryzacja). Wykres pozwala wysnuć jeszcze jeden wniosek: Polacy z wykształceniem zawodowym najczęściej ulegają tematom okładkowym, czego dowodzą przedstawione wyniki (najwyższe niemal przy każdym motywie).

\subsection{Miejsce zamieszkania}

Wyniki przeanalizowano poprzez pryzmat pięciu podgrup, czyli wsi, małego miasta, średniego miasta, dużego miasta i wielkiego miasta. W pierwszym przypadku (tabela 13), w związku z pozytywnym działaniem tematów okładkowych:

$6 \quad$ Warto dodać, że osoby z wykształceniem powyżej średniego ciągle uznają, że prasa nadal pełni kulturogenną funkcję (oceniając ją tak samo lub wyżej niż telewizję), co w kontekście doboru treści tematów okładkowych również może mieć istotne znaczenie. Por. Diagnoza społecznych zachowań czytelniczych w obrębie prasy drukowanej i cyfrowej, red. J. Poleszczuk, I. Anuszewska, Warszawa 2013, s. 5. 
- uwagę w najmniejszym stopniu zwracają sport, wulgarność, politycy i polityka, religia i nauka; a w największym: kulinaria, hobby, rodzicielstwo i dzieci, kultura i inne;

- do przejrzenia pisma najmniej zachęcają wulgarność, erotyka, przemoc, religia oraz politycy i polityka; zaś najbardziej - biznes i ekonomia, historia, hobby, poradnictwo, nauka;

- tematy okładkowe, które wpływają na zakup magazynów, to w najmniejszych stopniu wulgarność, przemoc, politycy i polityka, erotyka i religia; zaś w największym: inne, historie z życia wzięte, kulinaria, technologia, informacja.

Biorąc pod uwagę negatywne oddziaływanie tematów okładkowych, dostrzeżono, że:

- najrzadziej do przejrzenia zniechęcają poradnictwo, informacja, hobby, rodzicielstwo i historie z życia wzięte; najczęściej - erotyka, wulgarność, religia, przemoc, politycy i polityka;

- do kupna magazynu demotywują najmniej kulinaria, hobby, inne, nauka i rodzicielstwo; za to najbardziej - politycy i polityka, religia, erotyka i wulgarność.

Wśród powtarzających się motywów w zakresie pozytywnego oddziaływania tematów okładkowych najsłabiej wypadły wulgarność, religia, erotyka, przemoc oraz politycy i polityka; zaś najlepiej kulinaria, i hobby. Jeśli chodzi o negatywny wpływ tematów okładkowych na reakcje odbiorców, to powtarzają się (w zakresie najsłabszego działania) poradnictwo i hobby oraz (w zakresie najmocniejszego działania) - erotyka, wulgarność, religia, politycy i polityka.

Jak widać, mieszkańcy wsi nie mają problemu w określenie motywów, które ich najbardziej zniechęcają zarówno do kupna, jak i przeglądania pism (bardzo często to, co wskazywano jako czynniki demotywujące wypada źle w wynikach pokazujących pozytywny wpływ na reakcje odbiorców). W tej grupie znalazły się przemoc, wulgarność, politycy czy erotyka. Ciekawie przedstawia się tutaj religia, która raczej zniechęca do sięgnięcia po magazyn (ok. 38\% wskazań), zaś dla ok. $21 \%$ jest przyczyną rezygnacji z zakupu (zachęca do niego ok. 15\% badanych). To wynik zastanawiający - wydać by się mogło, że mieszkańcy wsi wskażą ten temat jako jeden z najbardziej skutecznych w działaniu sprzedażowym. Jest to jednak podejście stereotypowe, którego zasadność nieco podważają raporty, wskazujące na spadkowe trendy religijności na wsi (dokumenty potwierdzają, że odsetek osób wierzących jest na wsi nadal największy, ale od kilku lat można zaobserwować tu pewne zmiany) ${ }^{7}$. Mieszkańcy wsi pozytywnie reagują na poradnictwo, które zachęca do przejrzenia pisma. Opisywana podgrupa preferuje także informację i technologię, co ponownie nie ma nic wspólnego ze schematycznym myśleniem o wsi ${ }^{8}$.

CBOS, Religijność polskiej wsi - komunikat z badań, Warszawa, styczeń 2014, s. 2.

$8 \quad$ Na przykład w umiarkowanym stopniu kojarząc wieś z wykształceniem, oczytaniem czy innowacyjnością, por. CBOS, Wieś polska - stereotypy, Warszawa, styczeń 2014, s. 8-9. 


\section{OBLICZA MEDIÓW I KOMUNIKACJI}

\begin{tabular}{|c|c|c|c|c|c|c|c|c|c|}
\hline \multicolumn{10}{|c|}{ Pięć najmniej licznych wskazań na poszczególne motywy (wieś) } \\
\hline & $\begin{array}{c}\text { Zwracają moją } \\
\text { uwagę }\end{array}$ & & $\begin{array}{l}\text { Zachęcają mnie do } \\
\text { przejrzenia pisma }\end{array}$ & & $\begin{array}{l}\text { Zachęcają mnie } \\
\text { do kupna pisma }\end{array}$ & & $\begin{array}{c}\text { Zniechęcają mnie } \\
\text { do przejrzenia } \\
\text { pisma }\end{array}$ & & $\begin{array}{c}\text { Zniechęcają mnie do } \\
\text { kupna pisma }\end{array}$ \\
\hline Sport & $11,3 \%$ & Wulgarnośś & $5,5 \%$ & Wulgarność & $12,1 \%$ & Poradnictwo & $13,2 \%$ & Kulinaria & $2,6 \%$ \\
\hline Wulgarność & $11,9 \%$ & Erotyka & $6,5 \%$ & Przemoc & $12,8 \%$ & Informacja & $13,5 \%$ & Hobby & $6,1 \%$ \\
\hline $\begin{array}{c}\text { Politycy i } \\
\text { polityka }\end{array}$ & $14,0 \%$ & Przemoc & $9,8 \%$ & $\begin{array}{c}\text { Politycy i } \\
\text { polityka }\end{array}$ & $13,6 \%$ & Hobby & $14,8 \%$ & Inne & $6,1 \%$ \\
\hline Religia & $15,3 \%$ & Religia & $10,7 \%$ & Erotyka & $14,4 \%$ & $\begin{array}{c}\text { Rodzicielstwo / } \\
\text { dzieci }\end{array}$ & $15,1 \%$ & Nauka & $6,3 \%$ \\
\hline Nauka & $16,1 \%$ & $\begin{array}{l}\text { Politycy i } \\
\text { polityka }\end{array}$ & $10,8 \%$ & Religia & $14,7 \%$ & \begin{tabular}{|c|}
$\begin{array}{c}\text { Historie } \mathrm{z} \text { życia } \\
\text { wzięte }\end{array}$ \\
\end{tabular} & $16,0 \%$ & Poradnictwo & $6,8 \%$ \\
\hline
\end{tabular}

\begin{tabular}{|c|c|c|c|c|c|c|c|c|c|}
\hline \multicolumn{10}{|c|}{ Pięć najmniej licznych wskazań na poszczególne motywy (wieś) } \\
\hline & $\begin{array}{c}\text { Zwracają moją } \\
\text { uwagę }\end{array}$ & & $\begin{array}{l}\text { Zachęcają mnie do } \\
\text { przejrzenia pisma }\end{array}$ & & $\begin{array}{l}\text { Zachęcają mnie } \\
\text { do kupna pisma }\end{array}$ & & $\begin{array}{c}\text { Zniechęcają mnie } \\
\text { do przejrzenia } \\
\text { pisma }\end{array}$ & & $\begin{array}{c}\text { Zniechęcają mnie do } \\
\text { kupna pisma }\end{array}$ \\
\hline Kulinaria & $25,9 \%$ & $\begin{array}{c}\text { Biznes i } \\
\text { ekonomia }\end{array}$ & $24,2 \%$ & Inne & $30,2 \%$ & Erotyka & $33,5 \%$ & $\begin{array}{c}\text { Politycy i } \\
\text { polityka }\end{array}$ & $20,7 \%$ \\
\hline Hobby & $28,7 \%$ & Historia & $24,7 \%$ & $\begin{array}{c}\text { Historie z życia } \\
\text { wzięte }\end{array}$ & $31,0 \%$ & Wulgarność & $37,8 \%$ & Religia & $21,1 \%$ \\
\hline $\begin{array}{c}\text { Rodzicielstwo / } \\
\text { dzieci }\end{array}$ & $29,0 \%$ & Hobby & $24,8 \%$ & Kulinaria & $31,7 \%$ & Religia & $38,2 \%$ & Erotyka & $22,2 \%$ \\
\hline Kultura & $29,7 \%$ & Poradnictwo & $28,5 \%$ & Technologia & $35,4 \%$ & Przemoc & $40,7 \%$ & Sport & $24,5 \%$ \\
\hline Inne & $31,9 \%$ & Nauka & $30,1 \%$ & Informacja & $36,4 \%$ & $\begin{array}{l}\text { Politycy i } \\
\text { polityka }\end{array}$ & $40,9 \%$ & Wulgarność & $32,7 \%$ \\
\hline
\end{tabular}

Tabela 13. Treść tematów okładkowych a kategoria demograficzna (miejsce zamieszkania: wieś). Źródło: opracowanie własne na podstawie badań przeprowadzonych na ogólnopolskiej próbie liczącej N=1094 osób, dobranej z panelu Ariadna metodą CAWI. Odpowiadający: wszyscy badani.

W przypadku małych miast (tabela 14 ), w związku z pozytywnym działaniem tematów okładkowych:

- uwagę w najmniejszym stopniu zwracają wulgarność, politycy i polityka, biznes i ekonomia, gwiazdy popkultury i sport; zaś w największym: hobby, religia, rodzicielstwo i dzieci, kulinaria i tzw. inne;

- do przejrzenia pisma najmniej zachęcają gry komputerowe, erotyka, uroda, przemoc i wulgarność; zaś najbardziej - publicystyka, informacja, technologia, nauka i hobby;

- tematy okładkowe, które wpływają na zakup magazynów, to w najmniejszym stopniu politycy i polityka, wulgarność, gry komputerowe, przemoc, publicystyka; zaś w największym: uroda, kultura, motoryzacja, informacja i poradnictwo.

Biorąc pod uwagę negatywne oddziaływanie tematów okładkowych, zauważono, że:

- najrzadziej do przejrzenia zniechęcają informacja, hobby, nauka, poradnictwo i inne; najczęściej - przemoc, moda, erotyka, gwiazdy popkultury oraz politycy i polityka;

- do kupna magazynu demotywują najmniej rodzicielstwo, moda, technologia, nauka i informacja, za to najbardziej - uroda, sport, biznes, ekonomia, gry komputerowe i wulgarność.

Wśród powtarzających się motywów w zakresie pozytywnego oddziaływania tematów okładkowych najsłabiej wypadły wulgarność, przemoc, politycy i polityka oraz 
gry komputerowe, zaś najlepiej hobby i informacja. Jeśli chodzi o negatywny wpływ tematów okładkowych na reakcje odbiorców, to powtarzają się (w zakresie najsłabszego działania) informacja i nauka, a w zakresie najmocniejszego działania - nic (jest to pierwszy przypadek dla całych badań).

Osoby pochodzące $\mathrm{z}$ małych miast wykazują ciekawe podejście do religii, która zwraca ich uwagę i nie budzi negatywnych reakcji (np. zniechęcenia do zakupu lub przejrzenia pisma). Nieco lepiej w porównaniu z innymi grupami odbiorców wypadają też politycy - co prawda zniechęcają do przeglądania magazynów (ok. 42\%), ale nie pojawiają się w pierwszej piątce tematów, które demotywują do zakupu (podobnie, jak przemoc: zniechęcająca do przejrzenia, ale do kupna już w znacznie mniejszym zakresie). Gorzej odbierane są gry komputerowe, lub - co już typowe dla badania - wulgarność.

\begin{tabular}{|c|c|c|c|c|c|c|c|c|c|}
\hline \multicolumn{10}{|c|}{ Pięć najmniej licznych wskazań na poszczególne motywy (male miasto) } \\
\hline & $\begin{array}{c}\text { Zwracają moją } \\
\text { uwagę }\end{array}$ & & $\begin{array}{l}\text { Zachęcają mnie do } \\
\text { przejrzenia pisma }\end{array}$ & & $\begin{array}{c}\text { Zachẹcają mnie do } \\
\text { kupna pisma }\end{array}$ & & $\begin{array}{c}\text { Zniechęcają mnie do } \\
\text { przejrzenia pisma }\end{array}$ & & $\begin{array}{l}\text { Zniechęcają mnie do } \\
\text { kupna pisma }\end{array}$ \\
\hline Wulgarność & $2,6 \%$ & $\begin{array}{c}\begin{array}{c}\text { Gry } \\
\text { komputerowe }\end{array} \\
\end{array}$ & $7,0 \%$ & $\begin{array}{c}\text { Politycy i } \\
\text { polityka }\end{array}$ & $7,7 \%$ & Informacja & $7,7 \%$ & $\begin{array}{c}\text { Rodzicielstwo / } \\
\text { dzieci }\end{array}$ & $7,5 \%$ \\
\hline $\begin{array}{l}\text { Politycy i } \\
\text { polityka }\end{array}$ & $6,1 \%$ & Erotyka & $9,1 \%$ & Wulgarność & $8,3 \%$ & Hobby & $8,3 \%$ & Moda & $10,4 \%$ \\
\hline $\begin{array}{c}\text { Biznes i } \\
\text { ekonomia }\end{array}$ & $8,3 \%$ & Uroda & $11,8 \%$ & $\begin{array}{c}\text { Gry } \\
\text { komputerowe }\end{array}$ & $10,5 \%$ & Nauka & $9,5 \%$ & Technologia & $11,9 \%$ \\
\hline $\begin{array}{c}\text { Gwiazdy } \\
\text { popkultury }\end{array}$ & $9,0 \%$ & Przemoc & $12,5 \%$ & Przemoc & $11,0 \%$ & Poradnictwo & $11,0 \%$ & Nauka & $12,5 \%$ \\
\hline Sport & $11,2 \%$ & Wulgarność & $12,9 \%$ & Publicystyka & $12,1 \%$ & Inne & $11,5 \%$ & Informacja & $12,7 \%$ \\
\hline
\end{tabular}

\begin{tabular}{|c|c|c|c|c|c|c|c|c|c|}
\hline & \multicolumn{3}{|c|}{$\begin{array}{c}\text { Zięć najmniej licznych wskazá na poszczególne motywy (male miasto) } \\
\text { uwage }\end{array}$} & $\begin{array}{c}\text { Zachęcają mnie do } \\
\text { przejrzenia pisma }\end{array}$ & $\begin{array}{c}\text { Zachęcają mnie do } \\
\text { kupna pisma }\end{array}$ & $\begin{array}{c}\text { Zniechęcają mnie do } \\
\text { przejrzenia pisma }\end{array}$ & $\begin{array}{c}\text { Zniechęcają mnie do } \\
\text { kupna pisma }\end{array}$ \\
\hline Hobby & $19,7 \%$ & Publicystyka & $30,1 \%$ & Uroda & $29,4 \%$ & Przemoc & $33,2 \%$ & Uroda & $29,2 \%$ \\
\hline Religia & $20,2 \%$ & Informacja & $30,6 \%$ & Kultura & $29,5 \%$ & Moda & $34,9 \%$ & Sport & $29,8 \%$ \\
\hline $\begin{array}{c}\text { Rodzicielstwo / } \\
\text { dzieci }\end{array}$ & $21,3 \%$ & Technologia & $31,4 \%$ & Motoryzacja & $29,7 \%$ & Erotyka & $35,3 \%$ & $\begin{array}{c}\text { Biznes i } \\
\text { ekonomia }\end{array}$ & $30,6 \%$ \\
\hline Kulinaria & $25,8 \%$ & Nauka & $33,3 \%$ & Informacja & $36,1 \%$ & $\begin{array}{c}\text { Gwiazdy } \\
\text { popkultury }\end{array}$ & $40,1 \%$ & $\begin{array}{c}\text { Gry } \\
\text { komputerowe }\end{array}$ & $32,3 \%$ \\
\hline Inne & $28,7 \%$ & Hobby & $33,5 \%$ & Poradnictwo & $46,7 \%$ & $\begin{array}{c}\text { Politycy } \mathbf{i} \\
\text { polityka }\end{array}$ & $42,2 \%$ & Wulgarność & $43,6 \%$ \\
\hline
\end{tabular}

Tabela 14. Treść tematów okładkowych a kategoria demograficzna (miejsce zamieszkania: małe miasto). Źródło: opracowanie własne na podstawie badań przeprowadzonych na ogólnopolskiej próbie liczącej N=1094 osób, dobranej z panelu Ariadna metodą CAWI. Odpowiadający: wszyscy badani.

Dla średnich miast (tabela 15), w związku z pozytywnym działaniem tematów okładkowych:

- uwagę w najmniejszym stopniu zwracają wulgarność, politycy i polityka, religia, przemoc, historie z życia wzięte; zaś w największym: historia, uroda, informacja, hobby i tzw. inne;

- do przejrzenia pisma najmniej zachęcają wulgarność, erotyka, gry komputerowe, przemoc oraz politycy i polityka; zaś najbardziej - poradnictwo, rodzicielstwo, kulinaria, technologia, kultura;

- tematy okładkowe, które wpływają na zakup magazynów, to w najmniejszym stopniu wulgarność, przemoc, gwiazdy popkultury, politycy i polityka, gry komputerowe; zaś w największym: poradnictwo, kulinaria, hobby, nauka i historie z życia wzięte. 
Biorąc pod uwagę negatywne oddziaływanie tematów okładkowych, zauważono, że:

- najrzadziej do przejrzenia zniechęcają informacja, hobby, kultura, poradnictwo i historia; najczęściej - gry komputerowe, politycy i polityka, przemoc, erotyka i wulgarność;

- do kupna magazynu demotywują najmniej, kultura, informacja, poradnictwo, nauka i technologia; za to najbardziej - politycy i polityka, przemoc, gry komputerowe, religia i wulgarność.

Wśród powtarzających się motywów w zakresie pozytywnego oddziaływania tematów okładkowych najsłabiej wypadła wulgarność, przemoc, politycy i polityka oraz gry komputerowe, zaś najlepiej hobby, kulinaria i poradnictwo. Jeśli chodzi o negatywny wpływ tematów okładkowych na reakcje odbiorców, to powtarzają się (w zakresie najsłabszego działania) informacja, poradnictwo i kultura, a w zakresie najmocniejszego działania - gry komputerowe, politycy i polityka, przemoc i wulgarność.

Można stwierdzić, że mieszkańcy średnich miast nie lubią zbytnio gier komputerowych, które zniechęcają do przejrzenia pisma (35\%) i do kupienia go (prawie $20 \%$ ). W przypadku tej grupy widać także duże rozdrobnienie w odpowiedziach: niekiedy rozdźwięk między kategoriami o najgorszych i najlepszych wskazaniach jest niewielki, np. historie z życia wzięte zwracają uwagę ok. 20\% badanych, a pod ich wpływem pismo kupuje ok. 28\% respondentów).

\begin{tabular}{|c|c|c|c|c|c|c|c|c|c|}
\hline \multicolumn{10}{|c|}{ Pięć najmniej licznych wskazań na poszczególne motywy (średnie miasto) } \\
\hline & $\begin{array}{c}\text { Zwracają moja } \\
\text { uwagę }\end{array}$ & & $\begin{array}{l}\text { Zachęcają mnie do } \\
\text { przejrzenia pisma }\end{array}$ & & $\begin{array}{l}\text { Zachęcają mnie do } \\
\text { kupna pisma }\end{array}$ & & $\begin{array}{c}\text { Zniechęcają mnie do } \\
\text { przejrzenia pisma }\end{array}$ & & $\begin{array}{l}\text { Zniechęcają mnie do } \\
\text { kupna pisma }\end{array}$ \\
\hline Wulgarność & $12,2 \%$ & Wulgarność & $3,8 \%$ & Wulgarność & $6,8 \%$ & Informacja & $4,6 \%$ & Kultura & $3,8 \%$ \\
\hline $\begin{array}{l}\text { Politycy i } \\
\text { polityka }\end{array}$ & $16,4 \%$ & Erotyka & $10,1 \%$ & Przemoc & $13,1 \%$ & Hobby & $6,0 \%$ & Informacja & $3,9 \%$ \\
\hline Religia & $17,6 \%$ & $\begin{array}{c}\text { Gry } \\
\text { komputerowe }\end{array}$ & $10,2 \%$ & $\begin{array}{c}\text { Gwiazdy } \\
\text { popkultury }\end{array}$ & $14,1 \%$ & Kultura & $9,0 \%$ & Poradnictwo & $4,3 \%$ \\
\hline Przemoc & $17,6 \%$ & Przemoc & $15,3 \%$ & $\begin{array}{l}\text { Politycy i } \\
\text { polityka }\end{array}$ & $14,1 \%$ & Poradnictwo & $9,3 \%$ & Nauka & $4,4 \%$ \\
\hline $\begin{array}{c}\text { Historie } \mathrm{z} \text { życia } \\
\text { wżęte }\end{array}$ & $20,3 \%$ & $\begin{array}{l}\begin{array}{l}\text { Politycy i } \\
\text { polityka }\end{array} \\
\end{array}$ & $16,3 \%$ & $\begin{array}{c}\text { Gry } \\
\text { komputerowe }\end{array}$ & $14,4 \%$ & Historia & $10,0 \%$ & Technologia & $4,5 \%$ \\
\hline
\end{tabular}

\begin{tabular}{|c|c|c|c|c|c|c|c|c|c|}
\hline \multicolumn{10}{|c|}{ Pięć najmniej licznych wskazań na poszczególne motywy (średnie miasto) } \\
\hline & $\begin{array}{c}\text { Zwracają moją } \\
\text { uwagę }\end{array}$ & & $\begin{array}{c}\text { Zachęcają mnie do } \\
\text { przejrzenia pisma }\end{array}$ & & $\begin{array}{l}\text { Zachęcają mnie do } \\
\text { kupna pisma }\end{array}$ & & $\begin{array}{c}\text { Zniechęcają mnie do } \\
\text { przejrzenia pisma }\end{array}$ & & $\begin{array}{c}\text { Zniechęcają mnie do } \\
\text { kupna pisma }\end{array}$ \\
\hline Historia & $30,6 \%$ & Poradnictwo & $34,8 \%$ & Poradnictwo & $24,0 \%$ & $\begin{array}{c}\text { Gry } \\
\text { komputerowe }\end{array}$ & $35,0 \%$ & $\begin{array}{c}\text { Politycy i } \\
\text { polityka }\end{array}$ & $17,7 \%$ \\
\hline Uroda & $30,8 \%$ & \begin{tabular}{|c|}
$\begin{array}{c}\text { Rodzicielstwo / } \\
\text { dzieci }\end{array}$ \\
\end{tabular} & $35,6 \%$ & Kulinaria & $24,0 \%$ & $\begin{array}{c}\text { Politycy i } \\
\text { polityka }\end{array}$ & $35,5 \%$ & Przemoc & $17,9 \%$ \\
\hline Informacja & $35,1 \%$ & Kulinaria & $36,3 \%$ & Hobby & $24,8 \%$ & Przemoc & $36,0 \%$ & $\begin{array}{c}\text { Gry } \\
\text { komputerowe }\end{array}$ & $19,6 \%$ \\
\hline Hobby & $36,2 \%$ & Technologia & $37,9 \%$ & Nauka & $25,9 \%$ & Erotyka & $36,9 \%$ & Religia & $20,8 \%$ \\
\hline Inne & $38,2 \%$ & Kultura & $40,6 \%$ & \begin{tabular}{|c|}
$\begin{array}{c}\text { Historie } \mathrm{z} \text { życia } \\
\text { wzięte }\end{array}$ \\
\end{tabular} & $27,9 \%$ & Wulgarność & $47,6 \%$ & Wulgarność & $29,6 \%$ \\
\hline
\end{tabular}

Tabela 15. Treść tematów okładkowych a kategoria demograficzna (miejsce zamieszkania: średnie miasto). Źródło: opracowanie własne na podstawie badań przeprowadzonych na ogólnopolskiej próbie liczącej N=1094 osób, dobranej z panelu Ariadna metodą CAWI. Odpowiadający: wszyscy badani. 


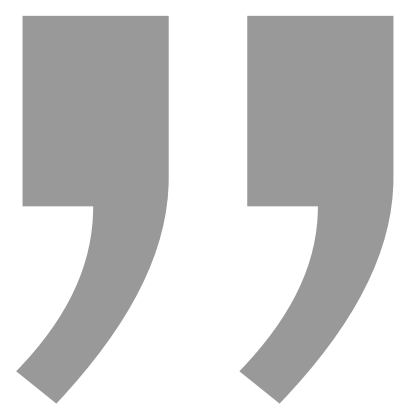

Można stwierdzić, że mieszkańcy średnich miast nie lubią zbytnio gier komputerowych, które zniechęcają do przejrzenia pisma (35\%) i do kupienia go (prawie 20\%), W przypadku tej grupy widać także duże rozdrobnienie w odpowiedziach: niekiedy rozdźwięk między kategoriami o najgorszych i najlepszych wskazaniach jest niewielki (...).

Wśród mieszkańców dużych miast (tabela 16):

- uwagę w najmniejszym stopniu zwracają wulgarność, erotyka, politycy i polityka, gwiazdy popkultury i publicystyka; zaś w największym informacja, sport, kulinaria, technologia, historie z życia wzięte;

- do przejrzenia pisma najmniej zachęcają wulgarność, politycy i polityka, przemoc, gry komputerowe i historie z życia wzięte; zaś najbardziej - nauka, historia, biznes i ekonomia, publicystyka i kultura;

- tematy okładkowe, które wpływają na zakup magazynów, to w najmniejszym stopniu wulgarność, przemoc, religia, politycy i polityka, historia; zaś w największym: hobby, nauka, tzw. inne, kulinaria i technologia.

Z kolei, biorąc pod uwagę negatywne oddziaływanie tematów okładkowych zauważono, że:

- najrzadziej do przejrzenia zniechęcają informacja, hobby, nauka, inne i publicystyka; najczęściej - erotyka, gry komputerowe, przemoc, wulgarność oraz politycy i polityka;

- do kupna magazynu demotywują najmniej technologia, gry komputerowe, kulinaria, nauka i informacja; za to najbardziej - politycy i polityka, religia, historie z życia wzięte, erotyka i wulgarność.

Wśród powtarzających się motywów w zakresie pozytywnego oddziaływania tematów okładkowych najsłabiej wypadły wulgarność, przemoc oraz politycy i polityka, zaś najlepiej kulinaria, technologia i nauka. Jeśli zaś chodzi o negatywny wpływ tematów okładkowych na reakcje odbiorców, to powtarzają się (w zakresie najsłabszego działania) informacja i nauka, a w zakresie najmocniejszego działania - erotyka, politycy i polityka i wulgarność. 


\section{OBLICZA MEDIÓW I KOMUNIKACJI}

Mieszkańcy dużych miast wybierają technologię, która wzbudza ich zainteresowanie (ok. 37\%) i zachęca do zakupów (ok. 29\%) - można założyć, że nabywanie pisma może tu mieć charakter impulsowy, niewiążący się z procesem przeglądania zawartości. W podobnym kontekście da się także ulokować motyw kulinariów (prawie 35\% zauważa takie tematy okładkowe, a nieco ponad $27 \%$ kupuje magazyn). Respondenci z tej grupy nie preferują religii (26\% temat ten ich zniechęca) czy historii z życia wziętych (tu dane są ciekawe: okazuje się, że motyw zwraca uwagę prawie $38 \%$ czytelników, ale zniechęca do zakupu niemal 29\%).

\begin{tabular}{|c|c|c|c|c|c|c|c|c|c|}
\hline \multicolumn{10}{|c|}{ Pięć najmniej licznych wskazań na poszczególne motywy (dużo miasto) } \\
\hline & $\begin{array}{c}\text { Zwracają moją } \\
\text { uwagę }\end{array}$ & & $\begin{array}{l}\text { Zachęcają mnie do } \\
\text { przejrzenia pisma }\end{array}$ & & $\begin{array}{l}\text { Zachęcają mnie do } \\
\text { kupna pisma }\end{array}$ & & $\begin{array}{l}\text { Zniechęcają mnie do } \\
\text { przejrzenia pisma }\end{array}$ & & $\begin{array}{c}\text { Zniechęcają mnie do } \\
\text { kupna pisma }\end{array}$ \\
\hline Wulgarność & $7,1 \%$ & Wulgarność & $4,5 \%$ & Wulgarność & $4,0 \%$ & Informacja & $1,6 \%$ & Technologia & $5,0 \%$ \\
\hline Erotyka & $12,9 \%$ & $\begin{array}{c}\begin{array}{c}\text { Politycy i } \\
\text { polityka }\end{array} \\
\end{array}$ & $9,6 \%$ & Przemoc & $6,8 \%$ & Hobby & $4,6 \%$ & $\begin{array}{c}\text { Gry } \\
\text { komputerowe }\end{array}$ & $9,9 \%$ \\
\hline $\begin{array}{l}\text { Politycy i } \\
\text { polityka }\end{array}$ & $14,1 \%$ & Przemoc & $10,3 \%$ & Religia & $7,5 \%$ & Nauka & $5,4 \%$ & Kulinaria & $11,9 \%$ \\
\hline $\begin{array}{c}\text { Gwiazdy } \\
\text { popkultury }\end{array}$ & $15,8 \%$ & \begin{tabular}{|c|} 
Gry \\
komputerowe
\end{tabular} & $11,6 \%$ & $\begin{array}{l}\text { Politycy i } \\
\text { polityka }\end{array}$ & $10,0 \%$ & Inne & $5,6 \%$ & Nauka & $13,6 \%$ \\
\hline Publicystyka & $16,3 \%$ & \begin{tabular}{|c|}
$\begin{array}{c}\text { Historie } \mathrm{z} \text { życia } \\
\text { wzięte }\end{array}$ \\
\end{tabular} & $13,6 \%$ & Historia & $11,4 \%$ & Publicystyka & $5,7 \%$ & Informacja & $14,1 \%$ \\
\hline
\end{tabular}

\begin{tabular}{|c|c|c|c|c|c|c|c|c|c|}
\hline & $\begin{array}{c}\text { Zwracają moją } \\
\text { uwagę }\end{array}$ & & $\begin{array}{c}\text { Zachęcają mnie do } \\
\text { przejrzenia pisma }\end{array}$ & $\begin{array}{c}\text { Zachęcają mnie do } \\
\text { kupna pisma }\end{array}$ & $\begin{array}{c}\text { Zniechęcają mnie do } \\
\text { przejrzenia pisma }\end{array}$ & $\begin{array}{c}\text { Zniechęcają mnie do } \\
\text { kupna pisma }\end{array}$ \\
\hline Informacja & $33,2 \%$ & Nauka & $30,5 \%$ & Hobby & $26,0 \%$ & Erotyka & $26,3 \%$ & $\begin{array}{c}\text { Politycy } \mathbf{i} \\
\text { polityka }\end{array}$ & $24,7 \%$ \\
\hline Sport & $33,7 \%$ & Historia & $32,7 \%$ & Nauka & $26,1 \%$ & $\begin{array}{c}\text { Gry } \\
\text { komputerowe }\end{array}$ & $32,9 \%$ & Religia & $26,1 \%$ \\
\hline Kulinaria & $34,7 \%$ & $\begin{array}{c}\text { Biznes i } \\
\text { ekonomia }\end{array}$ & $32,7 \%$ & Inne & $27,1 \%$ & Przemoc & $38,5 \%$ & Historie ż̇ycia \\
wzięte & $28,7 \%$ \\
\hline Technologia & $37,1 \%$ & Publicystyka & $34,9 \%$ & Kulinaria & $27,2 \%$ & Wulgarność & $41,5 \%$ & Erotyka & $32,0 \%$ \\
\hline $\begin{array}{c}\text { Historie ż̇̇ycia } \\
\text { wzięte }\end{array}$ & $37,5 \%$ & Kultura & $36,4 \%$ & Technologia & $29,2 \%$ & $\begin{array}{c}\text { Politycy i } \\
\text { polityka }\end{array}$ & $41,7 \%$ & Wulgarność & $43,0 \%$ \\
\hline
\end{tabular}

Tabela 16. Treść tematów okładkowych a kategoria demograficzna (miejsce zamieszkania: duże miasto). Źródło: opracowanie własne na podstawie badań przeprowadzonych na ogólnopolskiej próbie liczącej N=1094 osób, dobranej z panelu Ariadna metodą CAWI. Odpowiadający: wszyscy badani.

Wśród mieszkańców dużych miast (tabela 17):

- uwagę w najmniejszym stopniu zwracają wulgarność, historia, nauka, motoryzacja, przemoc; zaś w największym moda, biznes i ekonomia, informacja, uroda i tzw. inne;

- do przejrzenia pisma najmniej zachęcają wulgarność, gry komputerowe, politycy i polityka, erotyka i sport; zaś najbardziej - nauka, poradnictwo, kultura, technologia i historia;

- tematy okładkowe, które wpływają na zakup magazynów, to w najmniejszym stopniu wulgarność, przemoc, politycy i polityka, religia i technologia; zaś w największym sport, historie z życia wzięcie, nauka, hobby i motoryzacja.

Jeśli idzie o negatywne oddziaływanie tematów okładkowych, dostrzeżono, że:

- najrzadziej do przejrzenia zniechęcają informacja, hobby, kultura, nauka i moda; najczęściej - erotyka, gry komputerowe, przemoc, politycy i polityka oraz wulgarność; 
- do kupna magazynu demotywują najmniej informacja, kultura, nauka i hobby; za to najbardziej - erotyka, gwiazdy popkultury, religia, przemoc, i wulgarność.

Wśród powtarzających się motywów w zakresie pozytywnego oddziaływania tematów okładkowych najsłabiej wypadły wulgarność, przemoc oraz politycy i polityka, zaś najlepiej kulinaria, technologia i nauka. Jeśli zaś chodzi o negatywny wpływ tematów okładkowych na reakcje odbiorców, to powtarzają się (w zakresie najsłabszego działania) informacja i nauka, a w zakresie najmocniejszego działania - erotyka, przemoc i wulgarność.

Mieszkańcy wielkich miast nie zwracają uwagi na naukę, ale pod jej wpływem przeglądają i kupują pisma (prawie 35\% wskazań). Z kolei sport mniej przyczynia się do zaznajomienia się z zawartością, ale za to pozytywnie wpływa na zakupy (niemal 31\%), zaś motoryzacja zwraca uwagę niecałych $17 \%$ badanych, ale prowokuje decyzje zakupowe u ponad 35\%. Problemy ma religia, która zachęca do przejrzenie magazynu 11,6\% badanych i zniechęca do zakupu ponad $22 \%$.

\begin{tabular}{|c|c|c|c|c|c|c|c|c|c|}
\hline \multicolumn{10}{|c|}{ Pięć najmniej licznych wskazań na poszczególne motywy (wielkie miasto) } \\
\hline & $\begin{array}{c}\text { Zwracają moją } \\
\text { uwagę }\end{array}$ & & $\begin{array}{l}\text { Zachęcają mnie do } \\
\text { przejrzenia pisma }\end{array}$ & & $\begin{array}{l}\text { Zachęcają mnie do } \\
\text { kupna pisma }\end{array}$ & & $\begin{array}{c}\text { Zniechęcają mnie do } \\
\text { przejrzenia pisma }\end{array}$ & & $\begin{array}{l}\text { Zniechęcają mnie } \\
\text { do kupna pisma }\end{array}$ \\
\hline Wulgarność & $7,5 \%$ & Wulgarność & $4,0 \%$ & Wulgarność & $6,3 \%$ & Informacja & $5,7 \%$ & Poradnictwo & $5,8 \%$ \\
\hline Historia & $12,8 \%$ & $\begin{array}{c}\text { Gry } \\
\text { komputerowe }\end{array}$ & $10,9 \%$ & Przemoc & $7,1 \%$ & Hobby & $6,3 \%$ & Informacja & $6,5 \%$ \\
\hline Nauka & $15,1 \%$ & $\begin{array}{c}\text { Politycy i } \\
\text { polityka }\end{array}$ & $11,8 \%$ & $\begin{array}{c}\text { Politycy i } \\
\text { polityka }\end{array}$ & $11,1 \%$ & Kultura & $7,0 \%$ & Kultura & $7,2 \%$ \\
\hline Motoryzacja & $16,0 \%$ & Erotyka & $13,4 \%$ & Religia & $11,6 \%$ & Nauka & $8,5 \%$ & Nauka & $7,2 \%$ \\
\hline Przemoc & $16,7 \%$ & Sport & $16,0 \%$ & Technologia & $13,5 \%$ & Moda & $9,8 \%$ & Hobby & $7,7 \%$ \\
\hline
\end{tabular}

\begin{tabular}{|c|c|c|c|c|c|c|c|c|c|}
\hline \multicolumn{10}{|c|}{ Pięć najmniej licznych wskazań na poszczególne motywy (wielkie miasto) } \\
\hline & $\begin{array}{c}\text { Zwracają moją } \\
\text { uwagę }\end{array}$ & & $\begin{array}{c}\text { Zachęcają mnie do } \\
\text { przejrzenia pisma }\end{array}$ & & $\begin{array}{l}\text { Zachęcają mnie do } \\
\text { kupna pisma }\end{array}$ & & $\begin{array}{c}\text { Zniechęcają mnie do } \\
\text { przejrzenia pisma }\end{array}$ & & $\begin{array}{c}\text { Zniechęcają mnie } \\
\text { do kupna pisma }\end{array}$ \\
\hline Moda & $25,8 \%$ & Nauka & $34,4 \%$ & Sport & $30,9 \%$ & Erotyka & $24,2 \%$ & Erotyka & $20,6 \%$ \\
\hline $\begin{array}{c}\text { Biznes i } \\
\text { ekonomia }\end{array}$ & $26,3 \%$ & Poradnictwo & $37,5 \%$ & $\begin{array}{c}\begin{array}{c}\text { Historie z życia } \\
\text { wzięte }\end{array} \\
\end{array}$ & $32,5 \%$ & $\begin{array}{c}\text { Gry } \\
\text { komputerowe }\end{array}$ & $25,5 \%$ & $\begin{array}{c}\text { Gwiazdy } \\
\text { popkultury }\end{array}$ & $20,6 \%$ \\
\hline Informacja & $28,4 \%$ & Kultura & $43,6 \%$ & Nauka & $34,7 \%$ & Przemoc & $30,0 \%$ & Religia & $22,3 \%$ \\
\hline Uroda & $32,3 \%$ & Technologia & $45,5 \%$ & Hobby & $35,0 \%$ & $\begin{array}{c}\text { Politycy i } \\
\text { polityka }\end{array}$ & $40,0 \%$ & Przemoc & $24,6 \%$ \\
\hline Inne & $36,1 \%$ & Historia & $45,7 \%$ & Motoryzacja & $35,3 \%$ & Wulgarność & $50,9 \%$ & Wulgarność & $31,4 \%$ \\
\hline
\end{tabular}

Tabela 17. Treść tematów okładkowych a kategoria demograficzna (miejsce zamieszkania: wielkie miasto). Źródło: opracowanie własne na podstawie badań przeprowadzonych na ogólnopolskiej próbie liczącej N=1094 osób, dobranej z panelu Ariadna metodą CAWI. Odpowiadający: wszyscy badani.

Także i przy miejscu pochodzenia widać wyraźnie różnice między odpowiedziami poszczególnych podgrup (zbiorcze przedstawienie na rysunek 4). I tak, najczęściej pod wpływem gier komputerowych kupują mieszkańcy wielkich miast (także i oni chętnie wybierają sport), najrzadziej - małych miejscowości (pozostali bada- 
ni wskazują mniej więcej na podobne odpowiedzi). Odmiennie postrzegana jest technologia, najmniej interesująca dla rezydentów metropolii i średnich miast, a najbardziej dla wsi i miast małych. Widać także inne podejście do motoryzacji (preferowanej przez największe ośrodki, potem małe miasta, a najmniej - duże miasta), publicystyki (wybiera ją wieś, potem duże miasta, dalej średnie i wielkie, a na końcu - małe miasta) czy religii (najniżej notowanej wśród mieszkańców dużych i wielkich miast, zaś najwyżej wśród miast średnich). Dobre noty zyskuje poradnictwo (najlepiej wypada wśród wsi i małych miast) i nauka (tu preferują ją wielkie miasta). Pojawiają się natomiast motywy, które ocenione zostały najgorzej. Są to: wulgarność, przemoc, politycy i polityka.

\section{Zakończenie}

W niniejszym artykule zrealizowano wszystkie założone cele. Przede wszystkim zbadano reakcje polskich odbiorców na treści tematów okładkowych wykazując, które z tematów są najpopularniejsze i najmniej popularne ze względu na płeć, wiek, wykształcenie i miejsce zamieszkania respondentów. Zaprezentowano także rodzaj tych reakcji, dokumentując pozytywny (zachęcanie do przejrzenia i kupna, zwracanie uwagi) i negatywny (zniechęcenie do kupna i przeglądania pisma) wpływ 24 motywów tematycznych. Dodatkowo, każdy z podrozdziałów zakończono podsumowaniem danej kategorii, zarówno opisowym, jak i graficznym, zbiorczo prezentującym prosprzedażowe oddziaływanie omawianego zagadnienia.

Autorka pozytywnie zweryfikowała hipotezę, która brzmiała: „Dobór treści tematów okładkowych wiąże się z reakcjami polskich odbiorców, zachęcając lub zniechęcając ich do kontaktu z danym wydaniem magazynu, przy czym decyzje odbiorców uwarunkowane są ich przynależnością do wzmiankowanych kategorii demograficznych (co w sposób bezpośredni wiąże się z prowadzeniem działalności wydawniczej)”. Mimo tego, że konkretne dane zaprezentowano w treści artykułu (tabele), to warto tu podkreślić, że odpowiedzi wyszczególnionych demograficznie grup różnicowały się, głównie przy pozytywnym działaniu tematów okładkowych. Co prawda, dużą zbieżność można było zauważyć przy motywach zniechęcających do przejrzenia i zakupu magazynu (były to: politycy i polityka, przemoc, wulgarność, erotyka), ale - jak już zauważono ${ }^{9}$ - selekcja negatywna to także ważny komunikat, ostrzegający przed tym, co ewidentnie nie sprzeda pisma. To ponownie potwierdza konieczność daleko idącego dopasowywania tematów okładkowych do preferencji grup odbiorczych, polegającą nie tylko na odpowiednim doborze komponentów tychże tematów, ale również ich treści. Z tego punktu widzenia pozyskane wyniki są, zdaniem autorki, istotne $\mathrm{z}$ biznesowego punktu widzenia: po pierwsze, informują o gustach czytelników w zależności od przyjętej kategorii demograficznej. Po drugie - wskazują, które z treści warto eksponować na okładkach, by odbiorców pismem zainteresować, zachęcić do przeglądania, zakupu lub... przynajmniej do niego nie zniechęcić.

$9 \quad$ Zob.: A. Jupowicz-Ginalska, Tematy okładkowe polskich magazynów-elementy składowe i preferencje odbiorców, „Kultura - Media - Teologia” 2017 nr 28, s. 196-205. 
A. Jupowicz-Ginalska, Treść tematów okładkowych w magazynach...

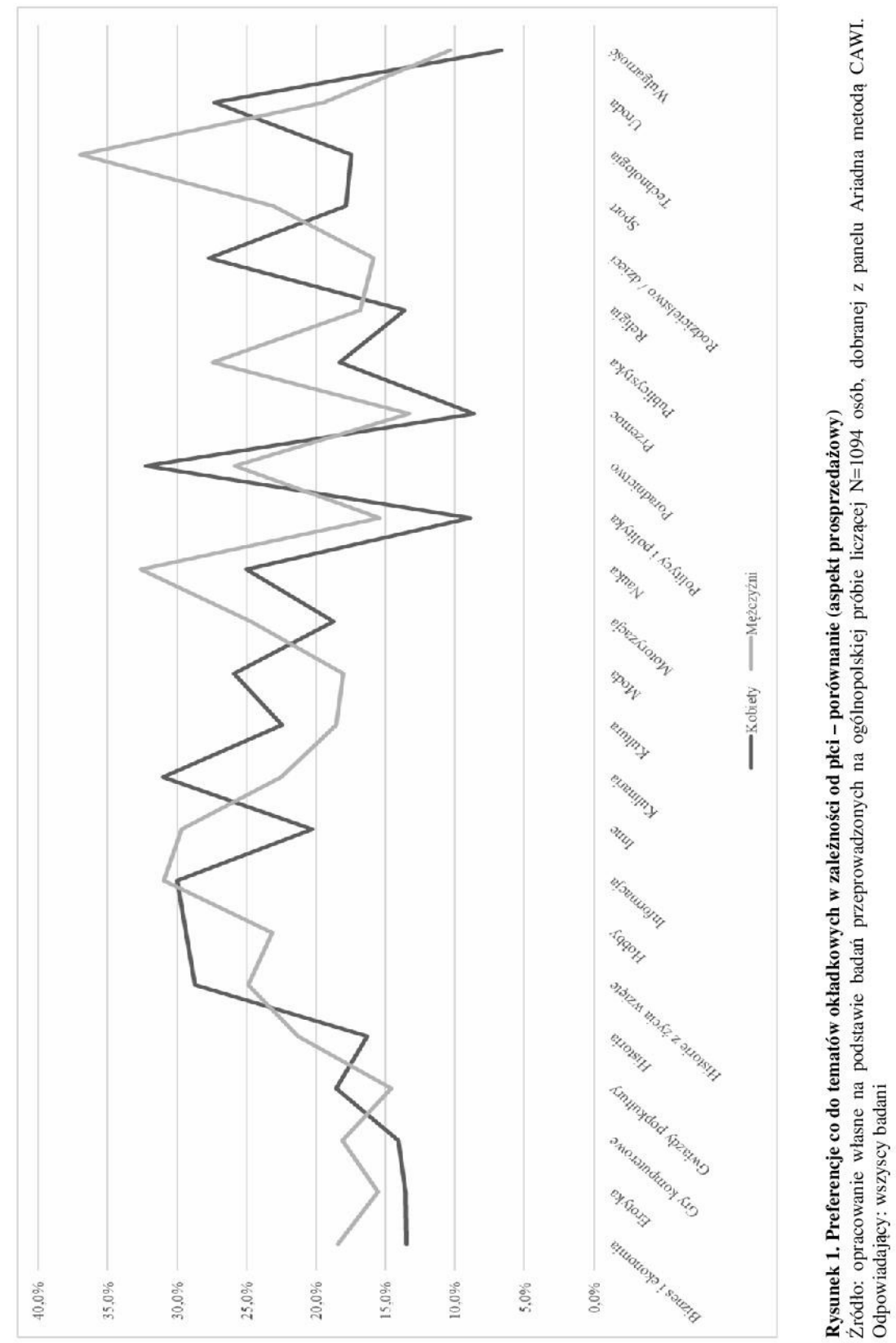




\section{OBLICZA MEDIÓW I KOMUNIKACJI}

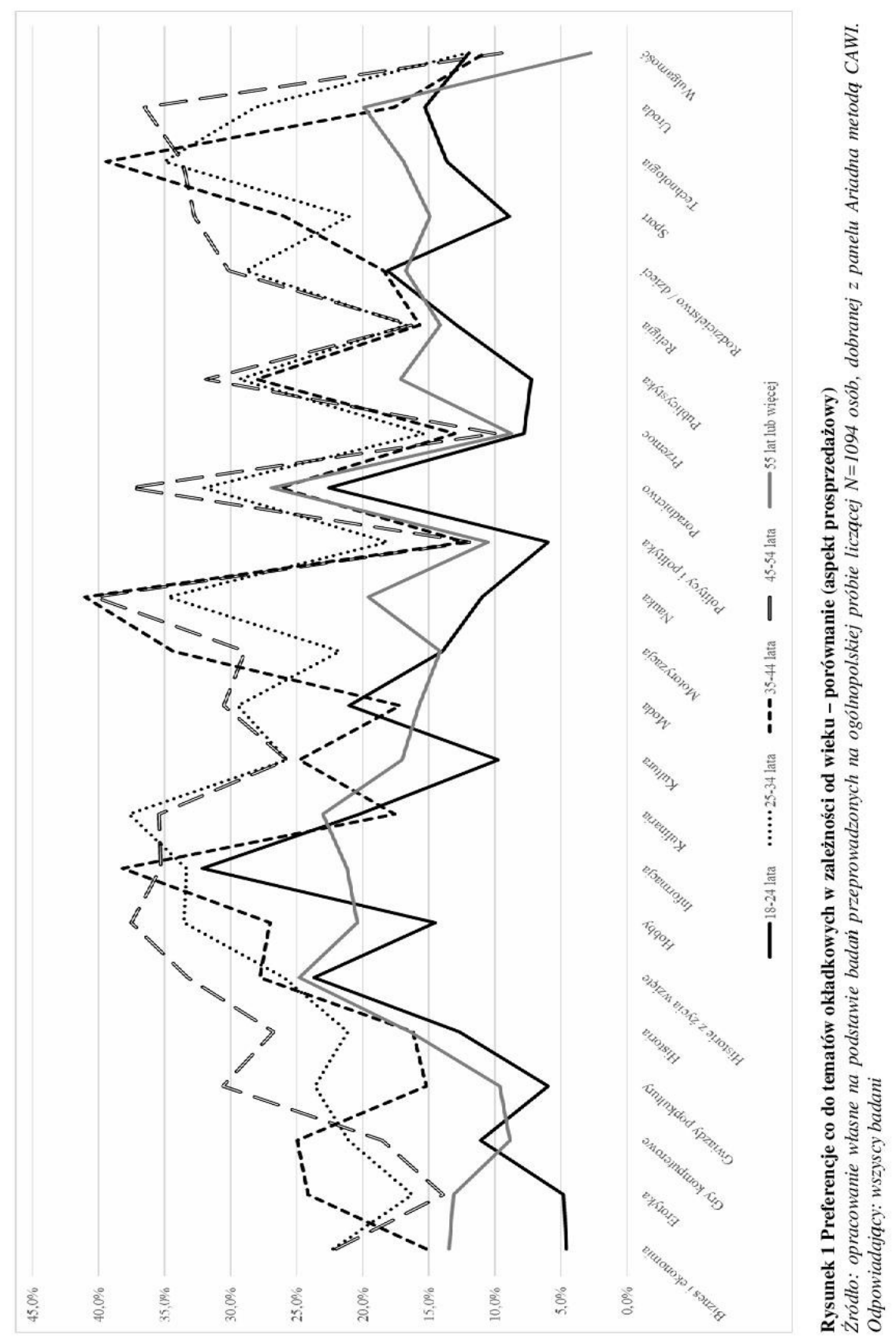


A. Jupowicz-Ginalska, Treść tematów okładkowych w magazynach...

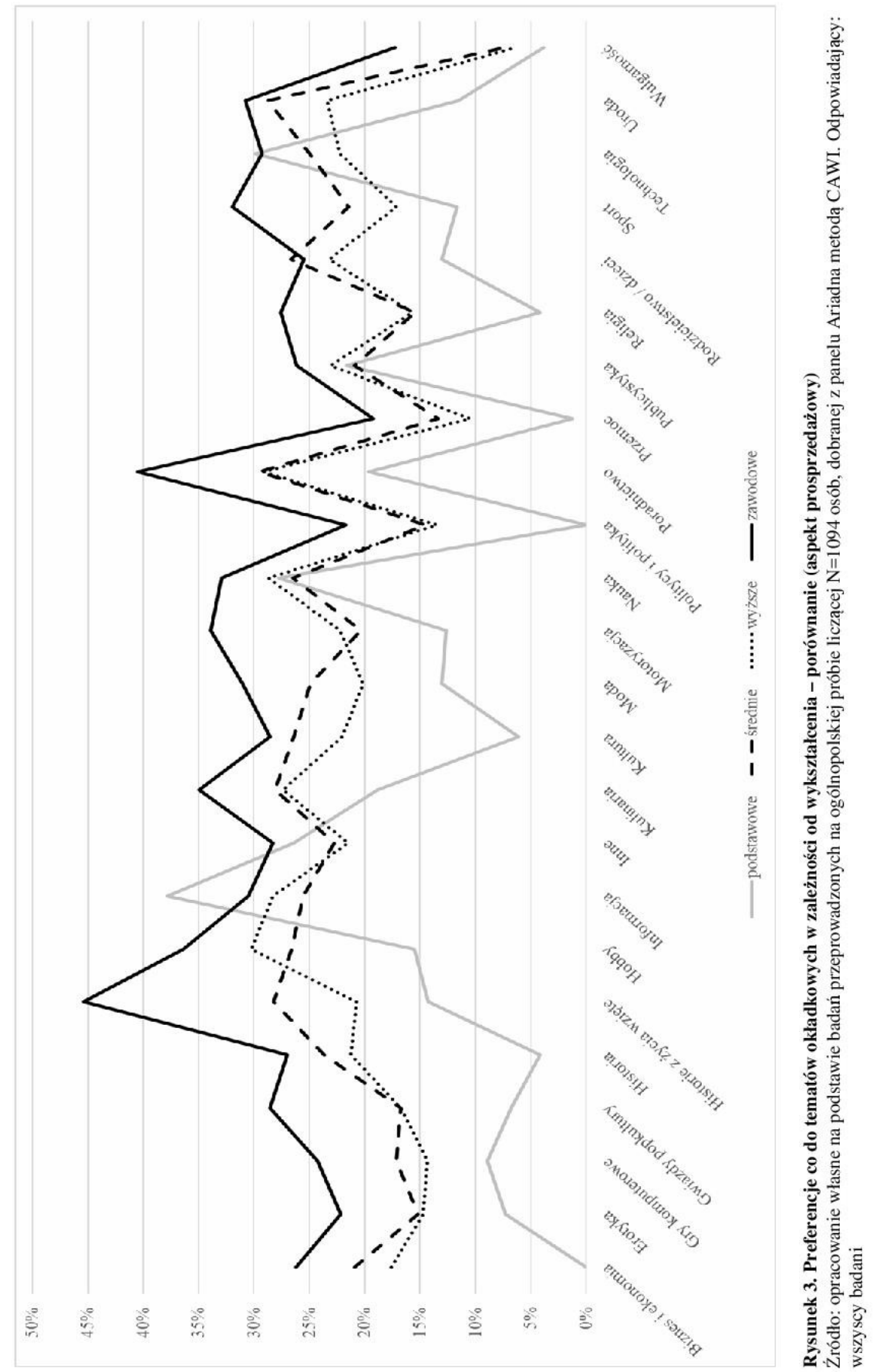




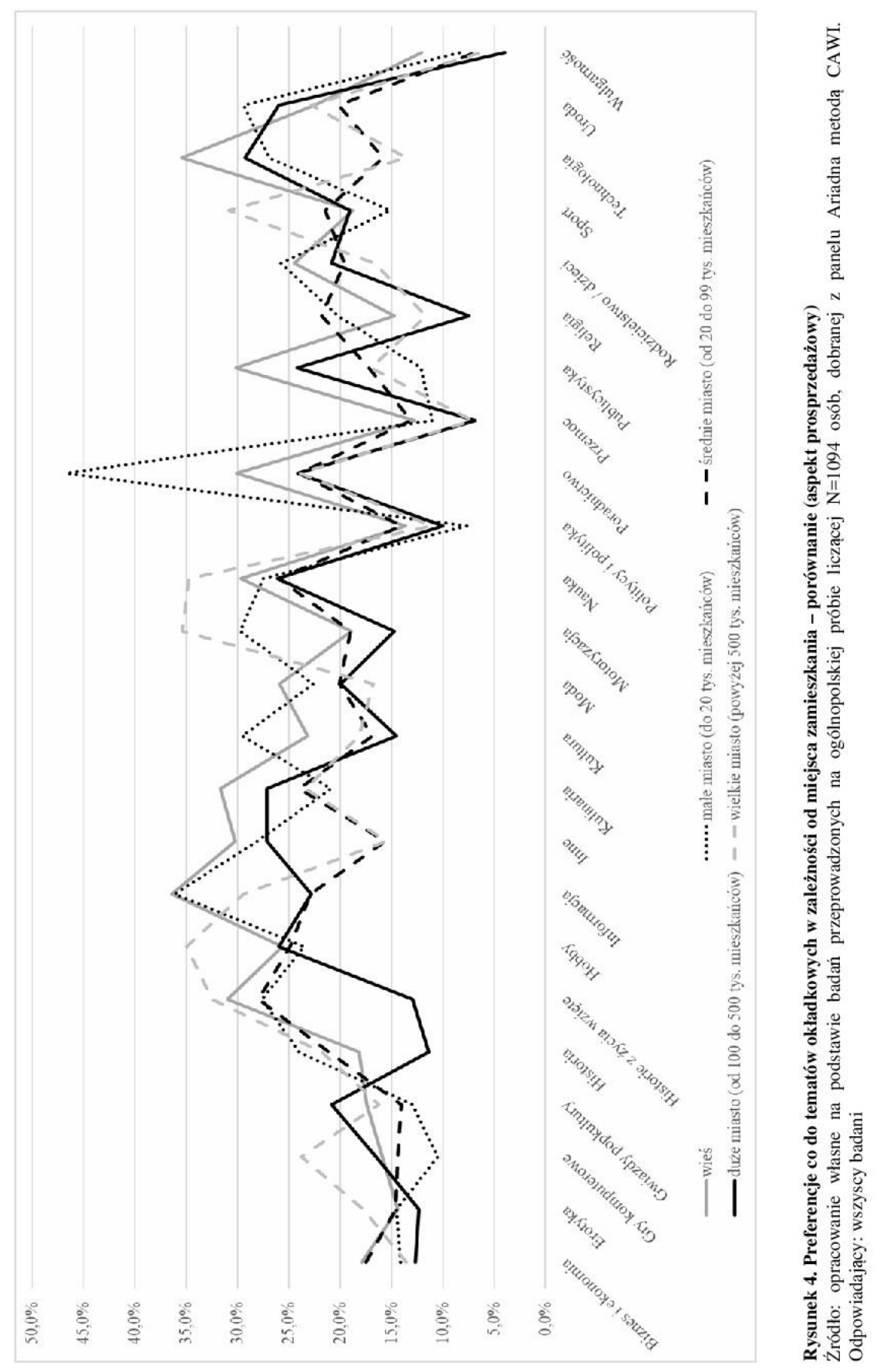




\section{BIBLIOGRAFIA:}

CBOS, Religijność polskiej wsi - komunikat z badań, Warszawa, styczeń 2014, s. 2.

CBOS, Wieś polska - stereotypy, Warszawa, styczeń 2014, s. 8-9.

Diagnoza społecznych zachowań czytelniczych w obrębie prasy drukowanej i cyfrowej, red. J. Poleszczuk, I. Anuszewska, Warszawa 2013.

Hajdas M., Wzorce męskości w komunikacji marki, „Uniwersytet Szczeciński Zeszyty Naukowe nr 866, Problemy zarządzania, finansów i marketingu" 2015, (numer 39), s. 26.

Jupowicz-Ginalska A., Tematy okładkowe polskich magazynów - elementy składowe i preferencje odbiorców, „Kultura - Media - Teologia” $2017 \mathrm{nr}$ 28, s. 196-205.

Panel Ariadna, https://panelariadna.pl/userpanel.php, dostęp: 15.05.2017.

Perchla-Włosik A., Młodzi mieszkańcy aglomeracji miejskich wobec mody jako elementu stylu życia, „Handel Wewnętrzny”2013, tom 1, s. 56.

Rybowska A., Stereotypy płci wyzwaniem dla marketingu, „Handel Wewnętrzny” 2013, tom 1, s. 98.

\section{O AUTORCE:}

Dr Anna Jupowicz-Ginalska - jedna z nielicznych badaczek w Polsce, specjalizująca się w tematyce marketingu środków przekazu. Wobszarze jej zainteresowań naukowych pozostają także: współczesne trendy w komunikacji marketingowej, opowieść transmedialna, popkultura, marketing show biznesu i manipulacja.

Jest autorką licznych publikacji naukowych na temat marketingu mediów, a jej książka „,Marketing medialny” otrzymała nagrodę główną w konkursie „Złote Skrzydła Dziennika Gazety Prawnej i KPMG 2011" (była to pierwsza kompletna publikacja z marketingu medialnego w Polsce).

Aktywnie uczestniczy w konferencjach ogólnopolskich i międzynarodowych, pojawia się $w$ mediach $w$ roli ekspertki z zakresu mediów i popkultury (m.in. $w$ Polsat News 2, Polsat, Polsat Cafe, TVP1, „Rzeczpospolita”, „Party”). Pozostaje także czynna zawodowo w sferze praktycznej: od 15 lat jest związana $z$ branżą promocyjną (głównie public relations). Pracowała m.in. wagencjach $P R$, korporacjach medialnych i administracji publicznej. Od 2010 do 2017 roku pelniła obowiązki Pełnomocnika Dziekana ds. Promocji Wydziału Dziennikarstwa i Nauk Politycznych UW oraz Wydziału Dziennikarstwa, Informacji i Bibliologii UW, m.in. organizując najważniejsze wydarzenia budujące wizerunek Wydziahu.Kontakt:a.ginalska@uw.edu.pl. 